\title{
Quantifying habitat use and preferences of pelagic seabirds using individual movement data: a review
}

\author{
Ewan D. Wakefield ${ }^{1, *}$, Richard A. Phillips ${ }^{1}$, Jason Matthiopoulos ${ }^{2}$ \\ ${ }^{1}$ British Antarctic Survey, Natural Environment Research Council, High Cross, Madingley Road, Cambridge CB3 0ET, UK \\ ${ }^{2}$ NERC Sea Mammal Research Unit, Gatty Marine Laboratory, University of St. Andrews, Fife KY16 8LB, UK
}

\begin{abstract}
Colonial seabirds are relatively easy to observe, count, measure and manipulate, and consequently have long been used as models for testing ecological hypotheses. A combination of animal tracking and satellite imagery has the potential to greatly inform such efforts, by allowing seabird-environment interactions to be observed remotely. We review how this can be achieved by applying innovative statistical techniques to quantify habitat use and preferences. Seabird movements are now observable at scales of meters using GPS loggers, and up to several years using lightbased geolocation, while satellite remote sensing systems, at resolutions of $\mathrm{km}$, are capable of characterizing the millions of $\mathrm{km}^{2}$ of habitat that are accessible to seabirds. Physical forcing and biological processes result in a hierarchical, patchy distribution of prey. Hence, analyses of seabird movements should be conducted at appropriate scales. Variation in habitat accessibility should also be considered: this declines with distance from the colony during the breeding season, when seabirds are central place foragers, and may be limited in the nonbreeding period by migration corridors that are defined by wind patterns. Intraspecific competition can further modify spatial usage, leading to spatial segregation of birds foraging from different colonies. We recommend that spatial usage be modeled as a function of habitat preference, accessibility and, potentially, competition. At the population level, this is currently best achieved using an empirical approach (e.g. using mixed-effects generalized additive models). At the individual level, more mechanistic models (e.g. state-space models) are more appropriate and have the advantage of modeling location errors explicitly.
\end{abstract}

KEY WORDS: Satellite tracking $\cdot$ GPS $\cdot$ Platform transmitter terminal $\cdot$ Geolocator $\cdot$ Spatial models Generalized additive model $\cdot$ State space models $\cdot$ Albatross

\section{INTRODUCTION}

Pelagic seabirds are large, long-lived and relatively easy to observe, capture, mark, and manipulate when they return to their colonies to breed. For these reasons, they have long been used as model organisms to address ecological questions, including those relating to the regulation of population size (Lack 1954, Wynne-Edwards 1962, Ashmole 1963), the influence of the central place constraint on foraging behavior (Orians \& Pearson 1979, Costa 1991), the response of populations to inter- and intraspecific competition (Croxall \& Prince 1980, Furness \& Birkhead 1984, Lewis et al. 2001), and environmental influences on life history traits (Lack 1968, Costa 1991, Weimerskirch 1992).
Although providing partial answers to these questions, early studies were necessarily colony-based and therefore hampered by a lack of knowledge of the movements and behavior of pelagic seabirds at sea (Ashmole 1971). Systematic observations from ships, which started in earnest in the 1970s (reviewed by Hunt et al. 1999, Ballance 2008), went some way to address this shortcoming. However, the spatiotemporal extent of such surveys was limited and it was not until the early 1990s, when it became possible to record the movements of individual seabirds using satellite-tracking devices (Jouventin \& Weimerskirch 1990, Prince et al. 1992), that this aspect of the lifestyles of seabirds could be investigated in detail. At the same time, in the field of oceanography, data provided by remote sensing 
technology has greatly improved our understanding of the effects of physical forcing on the marine environment (Longhurst 1998, Martin 2004). Furthermore, the development of auxiliary loggers for attachment to free-ranging birds has enabled the observation of an ever-increasing range of behaviors (Ropert-Coudert \& Wilson 2005).

Intuitively, it might be supposed that by combining the ever-increasing volumes of data provided by these technologies, the study of pelagic seabirds would result in further, significant advances in ecological theory. However, although many seabird tracking studies have had widespread impact (Weimerskirch et al. 1993, Weimerskirch et al. 1997a, Fauchald \& Tveraa 2003 are highly cited examples and many more are referred to in this review), we argue that a lack of access to appropriate statistical techniques has hampered further progress. Fortunately, in recent years, significant innovations have been made in the analysis of individual movements and spatial modeling (e.g. Aebischer et al. 1993, Jonsen et al. 2003, Aarts et al. 2008), which is a process to which seabird ecologists have themselves contributed (e.g. Fauchald \& Tveraa 2003, Pinaud \& Weimerskirch 2005). It is timely, therefore, to review the 'state of the art' and to make suggestions as to how these new and developing techniques might be more widely applied. In particular, we focus on quantifying and modeling habitat use and preferences of pelagic seabirds, using approaches analogous to those frequently used in the discipline of landscape ecology (Wiens et al. 1993, Lima \& Zollner 1996, Scott et al. 2002).

In this review, we use the term 'habitat' to refer to a set of environmental conditions rather than to geographical locations (Hall et al. 1997), and 'habitat use' to the proportion of time that an animal spends in a given habitat. Different habitats are rarely equally available, and 'habitat preference' is defined as the disproportionality between usage and availability, commonly their ratio (Manly et al. 2002). We define pelagic seabirds as those that derive their nourishment from the sea but do not forage in the intertidal, benthic or demersal zones. Hence, this group, which includes albatrosses, petrels, frigatebirds, tropicbirds, boobies, and some terns, (cf. Ashmole 1971) tends to comprise a single guild, i.e. wide-ranging, surface-feeding and relatively shallow-diving predators. It excludes deepdiving birds, such as penguins, cormorants and alcids (which have greater functional affinities with pinnipeds), gulls and most terns (which tend to feed inshore). The studies reviewed are inevitably dominated by those on larger birds such as albatrosses and some petrels, which were the first to be fitted with tracking devices. However, continued miniaturization is allowing the tracking of ever smaller species; hence, analytical techniques discussed will be applicable to all pelagic seabirds. Before describing these approaches in detail, we discuss the context of their application by considering issues of scale, measurement, behavior, habitat availability, accessibility and competition.

\section{SCALES OF PELAGIC SEABIRD-ENVIRONMENT INTERACTIONS}

It has long been acknowledged that physical and biological processes result in patchy distributions of habitats and organisms (Dubois 1975, Wiens 1976, Haury et al. 1977). Time lags tend to increase with spatial scale, thus these patches can usefully be regarded as forming a spatiotemporal hierarchy (Kotliar \& Wiens 1990). This approach is often seen in biological oceanography (Haury et al. 1977, Levin 1993), and has been applied more recently in studies of pelagic seabirds (Fauchald 1999, Fauchald et al. 2000, Pinaud \& Weimerskirch 2005). The hierarchical patch distribution of the lower and mid-trophic level organisms that constitute the prey of pelagic seabirds occurs as a consequence of both behavior (e.g. shoaling/swarming, and vertical and horizontal migration; Levin 1993, Folt \& Burns 1999) and physical forcing (e.g. Friedlaender et al. 2006, McGillicuddy et al. 2007, Sokolov 2008). Physical phenomena, such as wind and tide-induced overturning, currents, eddies, fronts and meanders (Fig. 1, Table 1) act, firstly, by transporting nutrients into the photic zone, stimulating new primary and secondary production (reviewed by Mann \& Lazier 2006), and secondly, by advecting and aggregating biomass (Perry et al. 1993, Abraham 1998, Bertrand et al. 2008). These processes may be in a steady state (e.g. geostrophic currents) or have a characteristic periodicity (e.g. tidal, diel, seasonal), whereas more episodic processes such as transient oceanic phytoplankton blooms, tend to be predictably related to other events such as winddriven mixing (Abbott \& Barksdale 1991).

Patches of habitat and prey occurring at different locations in this spatiotemporal hierarchy may be more or less profitable, or predictable, in their occurrence. For example, it is increasingly recognized that, at the mesoscale, the occurrence of the prey of temperate and polar pelagic seabirds is to some extent predictable, while that of tropical seabirds is less so (Hunt et al. 1999, Weimerskirch 2007, Weimerskirch et al. 2008) (to avoid ambiguity, we use the terms for spatial scale proposed by Haury et al. 1977; Fig. 2). Although the behavior of pelagic seabirds varies over timescales of seconds (Weimerskirch et al. 2005) to years (Phillips et al. 2005), and over distances of meters (Pennycuick 1982 ) to 10000 s of $\mathrm{km}$ (Shaffer et al. 2006), clear asso- 


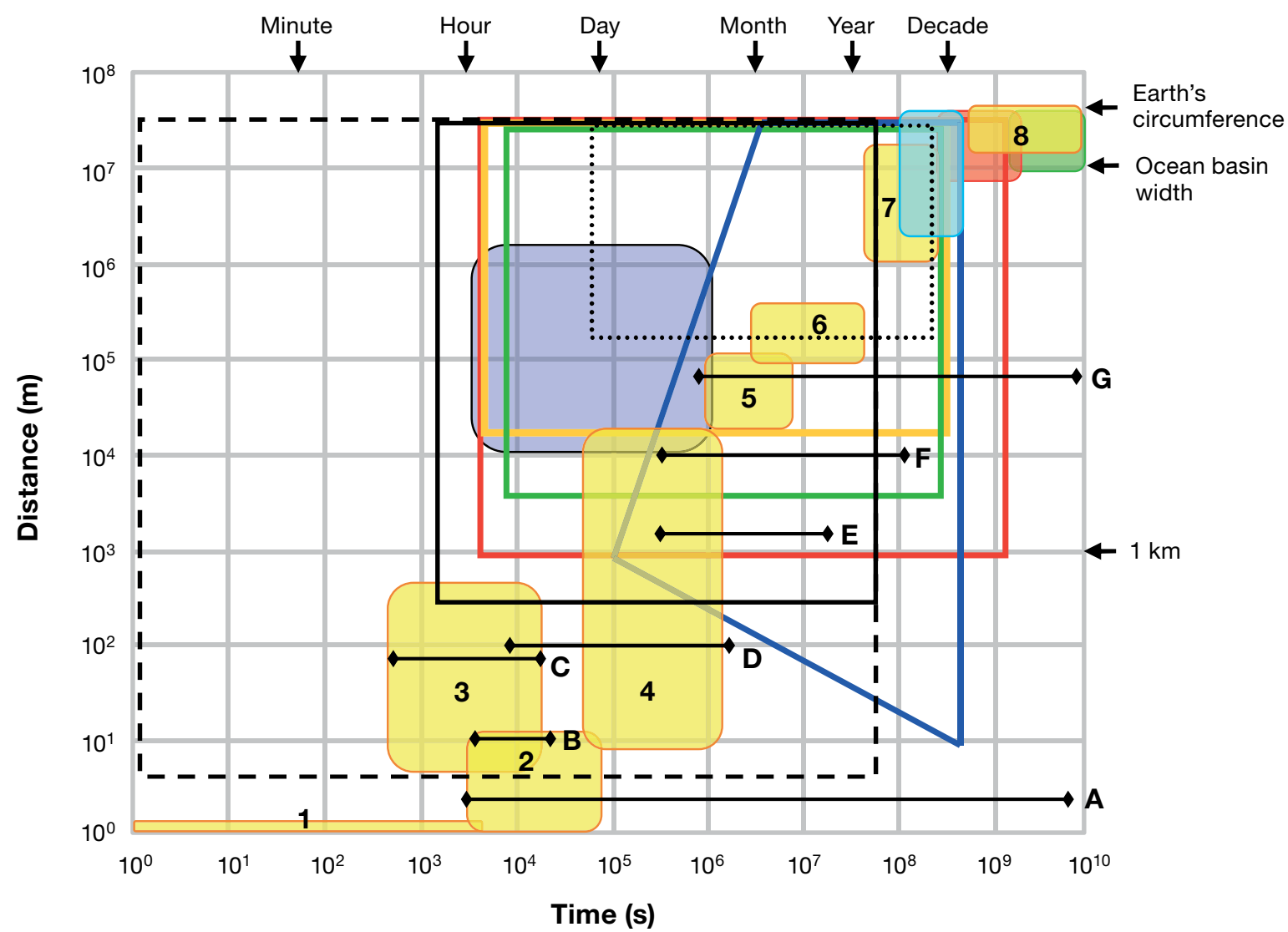

\section{Tracking systems Biophysical phenomena}

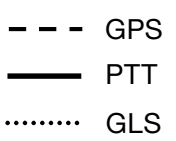

Remote sensing

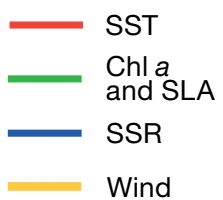

Turbulence

1. Micro scale

2. Fine scale

3. Langmuir convection

4. Submesoscale eddies

5. Mesoscale eddies

6. Warm/cold core rings

7. Ocean gyres

8. Thermohaline circulation

Horizontal variability

in mixed layer depth

El Niño-Southern Oscillation
Regime shifts

Long-term climate

fluctuations

Width \& lifetime of fronts associated with:

A. Freshwater plumes

B. Density compensation

C. Internal waves

D. Topographic features

E. Tidal mixing/shelf seas

F. Shelf break

G. Baroclinic currents

Fig. 1. Spatiotemporal scales of climatic and oceanographic processes compared to the resolution and coverage of human observation in pelagic seabird habitat studies. Tracking systems shown are PTTs (platform terminal transmitters), GPS tags and GLS (global location sensing, geolocator) tags. Remotely sensed variables include SST, chlorophyll a (chl a), Sea Level Anomaly (SLA), Sea Surface Roughness (SSR) and wind speed and direction. The spatiotemporal coverage achievable by ship-based surveys is limited by maximum vessel speed (assumed here to be 15 knots). Adapted from Kaiser et al. (2005) and Haury et al. (1977)

ciations are often seen at scales corresponding to the various biophysical phenomena that lead to patchiness. For example, shearwaters Puffinus spp. forage at shelf sea tidal fronts that are 10s of $\mathrm{km}$ long (Begg \& Reid 1997, Jahncke et al. 2005), and both large and medium-sized Procellariiformes congregate at coarse to mesoscale shelf break fronts (Hoefer 2000, Pinaud \&
Weimerskirch 2002). A diverse range of pelagic seabirds associate with the edges of mesoscale eddies (Nel et al. 2001, Weimerskirch et al. 2004), and many pelagic seabirds show affinities for eutrophic, mesotrophic or oligotrophic waters at coarse, meso- and macroscales (Hyrenbach et al. 2002, Awkerman et al. 2005, Pinaud \& Weimerskirch 2005). In the equatorial 


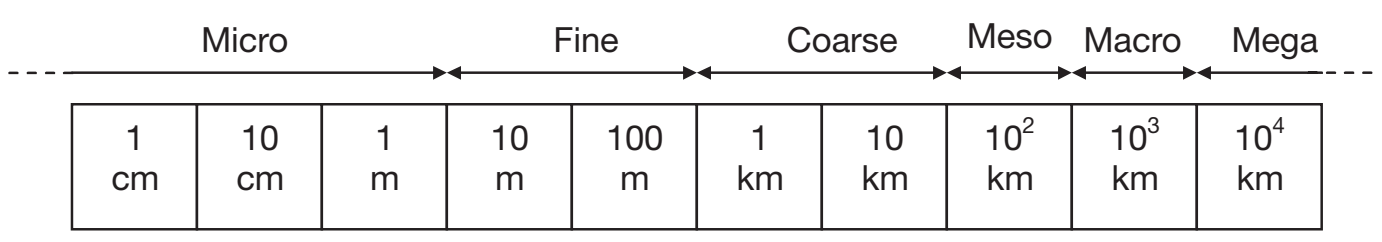

Fig. 2. Definition of terms used to describe spatial scale in habitat studies of pelagic seabirds (after Haury et al. 1977)

Table 1. Selected physical processes and marine phenomena, including: characteristic spatial and temporal scales; effects on primary production (PP), secondary production (SP) and biomass aggregation (AG); and areas in which they occur. Horizontal scale refers to diameter range of turbulent eddies; width range of Langmuir circulation and typical change in the mixed layer depth; typical width and length of fronts; width of polynyas and marginal ice zone (MIZ) and horizontal extent of other processes. Process tends to increase ( $\uparrow$ ), decrease $(\downarrow)$ or have both effects $(\mathfrak{l})$ on production; $(?)$ effect on production unknown; $(\checkmark)$ under the column AG indicates that the process tends to cause physical aggregation of biomass. Data based on Lutjeharms et al. (1985), Moore et al. (1999), Eldevik \& Dysthe (2002), Rudnick \& Martin (2002), Kaiser et al. (2005), Mann \& Lazier (2006). ACC: Antarctic Circumpolar Current, dec: decades

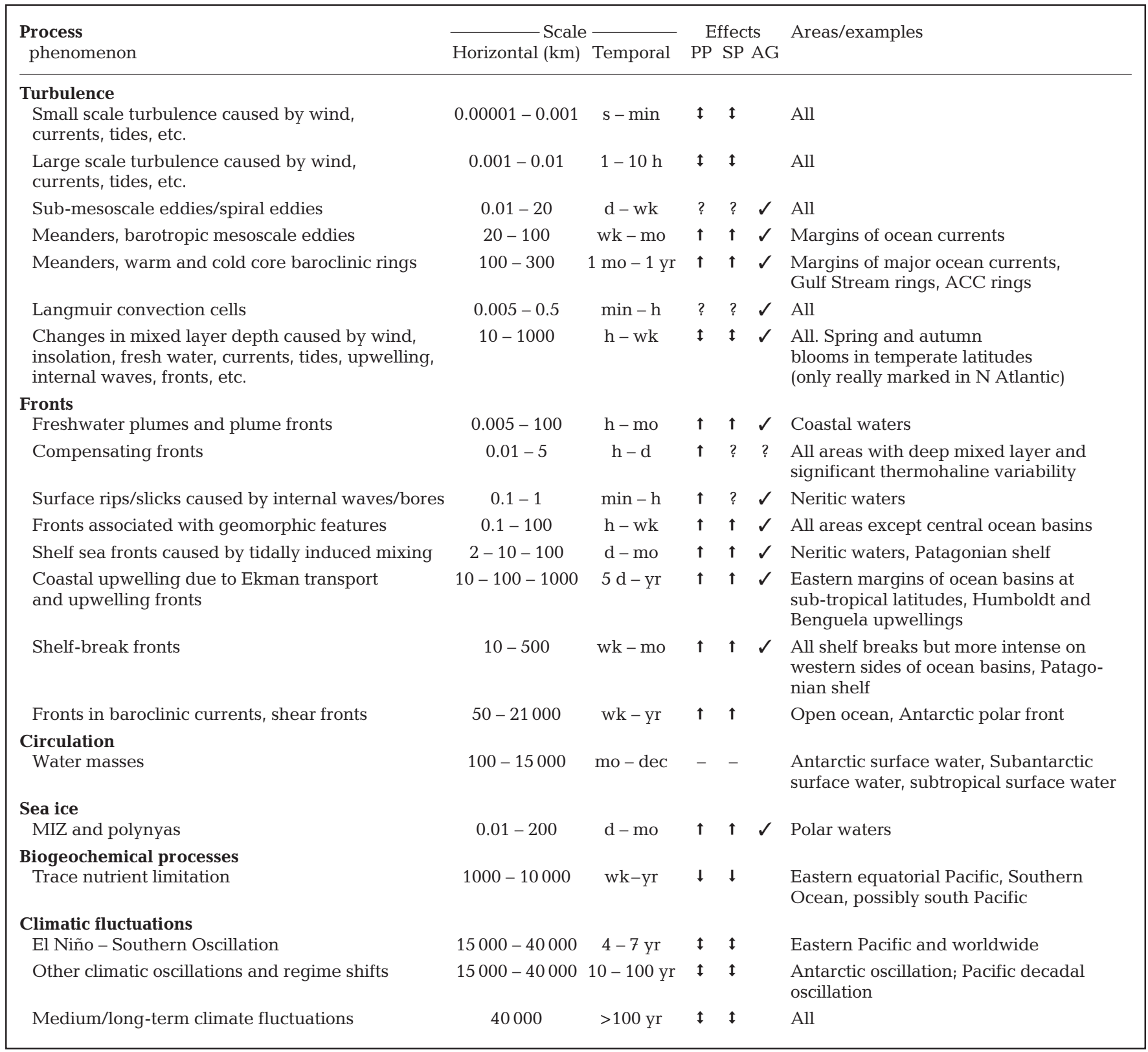


Pacific, piscivorous seabirds prefer well-stratified waters that are characterized by a deep and marked thermocline, whereas planktivores prefer areas with shallower, weaker thermoclines (Ribic et al. 1997, Spear et al. 2001, Vilchis et al. 2006). At the megascale, the global migratory movements of sooty shearwaters Puffinus griseus ensure that they are able to forage in highly productive upwelling areas year-round (Shaffer et al. 2006). Over decadal timescales, the association between sooty and pink-footed shearwaters $P$. creatopus with the California current system varies in parallel with the El Niño-Southern Oscillation (ENSO) (Oedekoven et al. 2001, Hyrenbach \& Veit 2003), and changes in the size and distribution of seabird colonies occur in response to regime shifts and climate fluctuations over still longer timescales (Olson \& Hearty 2003, Jenouvrier et al. 2005, Lewis et al. 2009).

That pelagic seabirds may express changes in habitat use and preference over such a wide range of scales raises a number of important analytical issues. Firstly, the observable window in the spatiotemporal spectrum is limited by the performance of both tracking and remote sensing systems (Fig. 1, discussed in detail below). This, in turn, limits the hypotheses that can currently be addressed using individual movement data. Similarly, the way that hypotheses are framed and tested may vary with scale (Levin 1992). If there is no a priori knowledge of the scale at which the phenomenon of interest occurs, then this can be determined either during exploratory data analysis using indirect techniques such as first-passage time analysis (see 'Behavior'), or by adopting a multi-scale approach (e.g. Garcia \& Ortiz-Pulido 2004, Suryan et al. 2006).

Table 2. Measurements made using satellite-borne instruments and the oceanographic processes and phenomena that they can identify (see 'Measuring the marine environment' for references)

\begin{tabular}{|c|c|c|c|}
\hline Variable & $\begin{array}{l}\text { Resolution } \\
\quad(\mathrm{km})\end{array}$ & $\begin{array}{l}\text { Revisit } \\
\text { time (d) }\end{array}$ & $\begin{array}{l}\text { Processes/phenomena detected in pelagic } \\
\text { seabird tracking studies (other examples) }\end{array}$ \\
\hline $\begin{array}{l}\text { Sea surface } \\
\text { temperature }\end{array}$ & $e^{1-4}$ & $0.25-3$ & $\begin{array}{l}\text { Water mass, baroclinic currents \& fronts } \\
\text { (mesoscale eddies \& meanders, shelf sea } \\
\text { fronts, shelfbreak fronts, coastal upwelling) }\end{array}$ \\
\hline $\begin{array}{l}\text { Sea surface } \\
\text { color }\end{array}$ & 4 & 1 & $\begin{array}{l}\text { Primary production (suspended sediment } \\
\text { and 'gelbstoffe' concentration, coastal } \\
\text { processes) }\end{array}$ \\
\hline Sea level & 4 & 1 & $\begin{array}{l}\text { Mesoscale eddies (meanders, shelf sea } \\
\text { fronts, shelfbreak fronts, baroclinic currents } \\
\text { and fronts, coastal upwelling, El Niño) }\end{array}$ \\
\hline $\begin{array}{l}\text { Passive } \\
\text { microwave }\end{array}$ & 25 & 1 & $\begin{array}{l}\text { Sea ice (water masses, baroclinic currents \& } \\
\text { fronts) }\end{array}$ \\
\hline Backscatter & $25-50$ & 1 & Wind field (sea ice) \\
\hline $\begin{array}{l}\text { Sea surface } \\
\text { roughness }\end{array}$ & $0.01-1$ & $3-35$ & $\begin{array}{l}\text { (Sub-mesoscale eddies, internal waves, } \\
\text { freshwater plumes and small-scale fronts, } \\
\text { sea ice concentration, polynyas) }\end{array}$ \\
\hline
\end{tabular}

\section{MEASURING THE MARINE ENVIRONMENT}

The spatiotemporal coverage and resolution of environmental data available to seabird ecologists is limited. Ship-based studies can record seabirds, prey and their environment simultaneously at high resolution (Fig. 1) (e.g. Pakhomov \& McQuaid 1996). Similarly, environmental data can be collected e.g. by some animal tracking devices (e.g. Shaffer et al. 2006), auxiliary loggers (reviewed by Wilson et al. 2002), autonomous buoys, and moorings. However, these approaches do not provide a synoptic view of all potentially available foraging areas (which could extend over millions of $\mathrm{km}^{2}$ ) that is necessary for habitat preference analyses. Hence, satellite remote sensing is generally the best source of environmental data.

Continuing innovation in satellite remote sensing is making more and higher resolution environmental variables available (Martin 2004). However, there are spatial and temporal limitations. Firstly, there is a tradeoff that tends to prioritize global or near-global data collection at the expense of resolution, such that sub-km phenomena remain poorly resolved (Table 2). Nevertheless, innovative instruments such as synthetic aperture radars (SAR) can now detect e.g. submesoscale eddies, freshwater plumes, sea ice, with a $10 \mathrm{~m}$ resolution (reviewed by Gens 2008). Secondly, only surface properties are measured by satellites. Although pelagic seabirds feed at or near the surface, their prey often include mesopelagic and deeper dwelling species (e.g. Croxall \& Prince 1980, Cherel \& Klages 1998). Inferences can be made about the 3-dimensional structure of water masses using remotely sensed sea level and sea surface temperature (SST), especially by using these data to drive numerical oceanographic models (Thorpe et al. 2005); these models can provide estimates of e.g. current velocity, temperature, salinity, at horizontal resolutions as low as $1 / 8^{\circ}(\sim 13 \mathrm{~km})$ throughout the water column (Aksenov \& Coward 2001). In addition, tags fitted to the animals themselves may be used to sample the water column (Wilson et al. 2002). Conductivity-temperaturedepth tags, which are large, have only been deployed on large animals such as pinnipeds (Biuw et al. 2007, Boehme et al. 2008), but smaller temperaturedepth recorders are deployed routinely on penguins. With continued miniaturization, these and similar instruments are likely to become more useful in the study of flying pelagic seabirds (Daunt et al. 2003, Garthe et al. 2007b). Thirdly, 
cloud cover renders many passive SST and chl a sensors ineffective (Woodward \& Gregg 1998). To achieve full spatial coverage, composite images (weekly or monthly) can be produced but this may result in poor resolution of dynamic mesoscale features (Uz \& Yoder 2004). In the case of SST, this problem is increasingly circumvented by the use of interpolated datasets. These combine multi-satellite and in situ data (e.g. from ships, ARGO floats) to provide daily cloud-free images at $1 / 20^{\circ}(\sim 6 \mathrm{~km})$ resolution, and are thus able to resolve all but very fine-scale features (Stark et al. 2007). Lastly, there may be spatiotemporal lags between the measurement of biophysical processes (the recession of sea ice, the shedding of mesoscale eddies) and their effects at higher trophic levels (see Mann \& Lazier 2006 for examples). The magnitude of such lags depends on many factors, including the rate at which primary production passes to higher trophic levels, which varies between ecosystems (Verity \& Smetacek 1996, Clarke 2003); the trophic level of the study species (Cherel et al. 2006); the rate of advection within the study area; and the movement capabilities of prey species themselves (e.g. Murphy et al. 2004). Although there may be enough information in some studies to determine likely lag times and/or distances a priori, potentially based on the relative timing of life history events and seasonal peaks in primary production (e.g. Laidre et al. 2008), it may be more pragmatic to investigate such effects on a studyby-study basis, by comparing the strength of relationships between spatial usage and biophysical covariates lagged at a range of plausible distances (e.g. Littaye et al. 2004, Croll et al. 2005).

Despite their limitations, remotely sensed environmental data can describe habitats in a biologically meaningful way (Table 2), especially when multiple variables are used synergistically to derive other descriptors of habitat, such as the rate of primary production (Behrenfeld \& Falkowski 1997), mixed layer depth (Zawada et al. 2005), and measures of mesoscale activity (e.g. eddy kinetic energy; Ducet et al. 2000), or to track the movement of fronts (Miller 2004). Finally, it can also be useful to consider indices of anthropogenic activity, especially fishing effort, in spatial usage/habitat studies. This is because some pelagic seabird species scavenge waste from, and/or target the same resources as fisheries (Petersen et al. 2008, Bugoni et al. 2009).

\section{TRACKING TECHNIQUES AND DATA PREPARATION}

The measurement of individual movement using tracking devices has been reviewed by Tremblay et al. (2009, this Theme Section), Burger \& Shaffer (2008) and Phillips et al. (2008). Briefly, platform terminal transmit- ters (PTTs) were first deployed on large species: giant petrels Macronectes spp. (Parmelee et al. 1985) and wandering albatrosses Diomedea exulans (Jouventin \& Weimerskirch 1990, Prince et al. 1992). Since then, almost all albatross species have been tracked (BirdLife International 2004), as have a growing number of other pelagic seabird taxa, increasingly using GPS tags. The species tracked vary from medium to large petrels, including Procellaria spp. (e.g. Freeman et al. 1997, Weimerskirch et al. 1999); Fulmarus spp. (e.g. Falk \& Moller 1995), Calonectris spp. (e.g. Gonzalez-Solis et al. 2007, Magalhães et al. 2008), and Puffinus spp. (e.g. Shaffer et al. 2006, Guilford et al. 2009), to sulids (e.g. Hamer et al. 2000, Weimerskirch et al. 2005) and frigatebirds Fregata spp. (Weimerskirch et al. 2004). The relatively large size and mass of tracking devices initially prevented their deployment on smaller species. It is generally accepted that payloads $>\sim 3 \%$ of body mass can result in behavioral changes (Kenward 2001, Phillips et al. 2003). Recently, however, species as small as the Cook's petrel Pterodroma cookii ( 200 g) have been tracked using archival geolocators (Rayner et al. 2008), which can weigh as little as $1 \mathrm{~g}$ (Mk. 10, British Antarctic Survey, Cambridge, UK).

PTTs, geolocators and GPS tags have very different performance characteristics (Fig. 1), there being a general trade-off between temporal resolution, deployment duration and device mass. PTTs use the ARGOS (CLS: Collecte Localisation Satellites) system to transmit location data via satellite to ground receiving stations, allowing animals to be tracked in near real time and without the need to recover the tag. PTTs can provide up to 40 locations $\mathrm{d}^{-1}$. However, the accuracy and precision of these locations are degraded by poor satellite visibility, changes in temperature, erratic tag movements and high speeds (Brothers et al. 1998, Britten et al. 1999, Vincent et al. 2002, Nicholls et al. 2007, Soutullo et al. 2007), all of which are characteristic of deployments on pelagic seabirds. Hence, locations received from these species tend to be of low quality, predominantly with ARGOS location classes of $0, \mathrm{~A}$, and B (Nicholls et al. 2007, Soutullo et al. 2007). Trials on free-ranging birds indicate that these location classes have a median (and 90th percentile) accuracy of 7 (29), 13 (87), and 35 (209) km respectively, with accuracy being log-normally distributed (Soutullo et al. 2007). Transitions between behaviors such as resting, commuting, searching, and diving, may result in systematic changes in accuracy and precision, but these and many other aspects of errors associated with ARGOS locations for free-ranging seabirds have not been quantified (Nicholls et al. 2007). This shortcoming could be addressed by comparing PTT and GPS locations received from seabirds (Soutullo et al. 2007). Despite these issues, PTTs remain useful, especially for 
tracking small to medium-sized ( 300-1000 g) species (Soutullo et al. 2007).

Given their considerably better accuracy ( 95\% of locations are within $10 \mathrm{~m}$ of the true location; Steiner et al. 2000, Fukuda et al. 2004), GPS tags are increasingly used in preference to PTTs (Weimerskirch et al. 2002, Grémillet et al. 2004, Awkerman et al. 2005). They also have the advantage of obtaining locations at high temporal resolutions (up to $1 \mathrm{~Hz}$, for periods of hours), allowing fine-scale behavioral information to be inferred from movement (Weimerskirch et al. 2007, Guilford et al. 2008). Initially, GPS units were archival and thus had to be retrieved to obtain data. However, integration with the ARGOS system now allows data to be received via satellite (Yasuda \& Arai 2005), and solar powered combined GPS-PTT devices have been deployed for $>2$ yr (e.g. Urios et al. 2007).

Geolocators record ambient light levels, which, following tag retrieval, are used to derive 2 positions $\mathrm{d}^{-1}$, with comparatively low mean accuracy of $\sim 190 \mathrm{~km}$ ( $\pm 110 \mathrm{~km}$ SD) (Phillips et al. 2004a). Although lightbased geolocation cannot provide useable latitude estimates around the equinoxes, some loggers also record temperature, which in combination with remotely sensed SST data can improve accuracy (Teo et al. 2004, Shaffer et al. 2005). Compared to PTTs and GPS loggers, geolocators are smaller, cheaper and can be attached to the bird's tarsus, allowing multiyear deployments and larger sample sizes (e.g. Phillips et al. 2005).

Given the inaccuracies inherent, to a certain degree, in data provided by all tracking devices, improbable positions are often removed by filtering prior to detailed analysis (e.g. McConnell et al. 2002), and missing locations estimated by linear or curvilinear interpolation (e.g. Tremblay et al. 2006). Alternatively, by assuming that animals move in random walks, probabilistic estimates of locations can be made (Horne et al. 2007, Bost et al. 2009). However, the assumptions implicit in such preliminary procedures may bias further analysis. For example, albatross tracking data have been filtered such that locations resulting in speeds $>80 \mathrm{~km} \mathrm{~h}^{-1}$ are flagged as erroneous. In reality, birds flying in strong tail winds have been shown to fly well in excess of this speed (Catry et al. 2004a). Ideally, therefore, observation error and movement biology should be dealt with simultaneously, as in the state-space modeling approach (SSM) (Patterson et al. 2008).

\section{BEHAVIOR}

Birds may engage in many different behaviors, including foraging, commuting, migrating, preening, and resting. These may be initiated by exogenous (e.g. a change in wind direction or movement into a prey patch) or endogenous (e.g. physiological state) cues. Hence, habitat use and preference is dependent on time-activity budgets, which in turn change with life history stage, environmental conditions, and other factors (Phalan et al. 2007, Guilford et al. 2009). As such, behavioral state is informative of habitat use and preference, and vice versa. During breeding, pelagic seabirds tend to commute to and from areas with more or less predictable resources (Weimerskirch 2007), so a key aim is often to distinguish between putative commuting (or taxis) and searching (or foraging) behavior (Lima \& Zollner 1996). Hence, many individual-based studies aim to infer behavioral state from measures of path geometry, such as speed and direction (Johnson et al. 2002, Jonsen et al. 2007). At all but the microscale, tracks tend to deviate from straight lines; hence, the divergence of the measured from the actual route increases with the time interval between locations (Alerstam et al. 1993). Very low speeds occur when birds are not in flight, and are thus variously interpreted as foraging (Weimerskirch et al. 1997b, Weimerskirch \& Guionnet 2002), resting (Nel et al. 2001), waiting for favorable winds (Murray et al. 2002), or rafting prior to entering a colony (Awkerman et al. 2005, Guilford et al. 2008). However, these behaviors have not yet been distinguished using path geometry alone.

It is assumed that birds that are traveling follow direct paths and move at high speeds at all scales of measurement, whereas, based on theoretical predictions and observations of birds at sea, regular changes in flight direction and low speeds are considered indicative of foraging - a behavior termed as arearestricted search (ARS) (reviewed by Kareiva \& Odell 1987). Hence, speed (Fernandez \& Anderson 2000, Nel et al. 2001, Hyrenbach et al. 2002), turning angle (Fernandez et al. 2001, Huin 2002), coefficient of concentration (Hyrenbach et al. 2002, Hyrenbach \& Dotson 2003), residence time (Prince et al. 1998), fractal dimension (Nams 2005, Tremblay et al. 2007) and firstpassage time (FPT; Fauchald \& Tveraa 2003, Pinaud \& Weimerskirch 2005) have all been used as indirect indices of ARS. Peaks in the variance of FPT, which is the time required for an animal to cross a circle of a given radius, indicate the spatial scales at which birds carry out ARS (Fauchald \& Tveraa 2003, Pinaud \& Weimerskirch 2005), making it a particularly useful tool for exploratory data analysis. However, the spatial resolution achievable with FPT and fractal dimension analyses is limited by that of the tracking data, such that results obtained from analyses of ARGOS locations may be unreliable at coarse to fine scales (Bradshaw et al. 2007, Pinaud 2008). Furthermore, although it may be intuitive to suppose that more tortuous tracks indicate foraging, this assumption, and perhaps more importantly its corollary that birds engaged in direct 
movement are not foraging, has rarely been tested. Indeed, there is evidence to the contrary: grey-headed albatrosses Thalassarche chrysostoma are capable of foraging successfully even in very rapid (>110 $\left.\mathrm{km} \mathrm{h}^{-1}\right)$, directed flight (Catry et al. 2004a); wandering albatrosses fitted with stomach temperature loggers do not capture prey at high rates during bouts of ARS (Weimerskirch et al. 2007); and tracks with ARS-like properties can arise due to location errors (Robinson et al. 2007, Pinaud 2008).

Auxiliary loggers are increasingly used to collect behavioral data (reviewed by Ropert-Coudert \& Wilson 2005). Frequent landings and takeoffs recorded by activity loggers are regarded as indicative of foraging (Weimerskirch et al. 1997b), and time-depth recorders (Shaffer et al. 2006, Weimerskirch et al. 2008) and, particularly, stomach temperature loggers (Weimerskirch et al. 1994, Catry et al. 2004b), provide more direct measures. Accelerometers have been used to identify diving, feeding and flight behavior (RopertCoudert \& Wilson 2005, Weimerskirch et al. 2005). However, regardless of whether behavioral state is measured directly or inferred from path geometry, it should be cautioned that although some behavioral states are inherently categorical (e.g. in flight vs. not in flight), others may fall on a continuous spectrum (e.g. commuting vs. ARS) and should be treated as such during analyses.

\section{HABITAT AVAILABILITY AND ACCESSIBILITY}

The processes leading to patchiness in the distribution of pelagic resources also result in differences in the relative availability of habitats. Although incorporated in some recent studies of pelagic habitat preference (e.g. Pinaud et al. 2005, Louzao et al. 2006, Redfern et al. 2006), the geographical area under scrutiny is often defined arbitrarily by a boundary that broadly encompasses the known foraging range. A more biologically meaningful approach would be to consider the area bounded by a species' maximum foraging range from a particular colony (Awkerman et al. 2005). Furthermore, within this area, the energetic and temporal costs of moving to different habitats may differ. Hence, during breeding, when birds act as central place foragers, habitat accessibility varies inversely with distance from the colony (Orians \& Pearson 1979, Matthiopoulos 2003). Furthermore, as with other marine central place foragers, such as pinnipeds and penguins (Thompson et al. 2003, Boersma \& Rebstock 2009), the severity of the central place constraint, and therefore the potential foraging range, varies with breeding stage (Weimerskirch et al. 1993, Shaffer et al. 2003). Although the majority of tracking studies have been carried out on breeding birds, analyses of habitat use have generally not accounted for these constraints. Yet, colony distance can be included as a candidate explanatory covariate in spatial usage models (Louzao et al. 2006), and an even more systematic approach would be to compare observed spatial usage to a null model in which available habitats are sampled quasirandomly, at a rate proportional to accessibility (Matthiopoulos 2003, Aarts et al. 2008). In the latter case, the apparent availability of habitats then becomes dependent not only on their spatial extents, but also on distance from the colony.

Recent research has highlighted the effects of wind on the energetic and temporal costs incurred by seabirds during flight (Weimerskirch et al. 2000, Suryan et al. 2008, Wakefield et al. in press). Flight performance is partly dependent on wing loading, leading to suggestions that birds with higher wing loadings are better adapted to windier areas (Shaffer et al. 2001, Suryan et al. 2008). Migrating and breeding Procellariiformes route their journeys and make behavioral decisions so as to exploit favorable winds at fine to mega-scales (Murray et al. 2003, Shaffer et al. 2006, Felicisimo et al. 2008). For example, using a grid-based mechanistic model, geolocator and remotely sensed wind data, Felicisimo et al. (2008) showed that Cory's shearwaters follow least cost paths during migration. Indeed, many pelagic seabirds may be constrained during nonbreeding periods to use discrete migration corridors (Gonzalez-Solis et al. 2007, Guilford et al. 2009), and to windier areas in general, limiting habitat accessibility during such periods. Furthermore, because adults gain mass when collecting prey for their chick, it has been hypothesized that prevailing winds can lead to asymmetry in the accessibility of areas upand downwind of colonies (Pennycuick 1989). Hence, wind may affect accessibility during both breeding and nonbreeding stages. However, the pelagic wind field is highly dynamic and modeling its effect on transport costs and accessibility is challenging.

\section{INTER- AND INTRASPECIFIC INTERACTIONS}

The spatial usage of animals may vary in response to both inter- and intraspecific competition. The latter is often more intense because of the lack of niche partitioning between conspecifics (Begon et al. 2006). In central place foragers, such as colonial insects and land birds, direct intraspecific competition may result in the spatial partitioning of foraging areas (Dukas \& Edelstein-Keshet 1998, Adler \& Gordon 2003). An analogous situation arises in seabirds foraging from adjacent colonies (e.g. Huin 2002, Ainley et al. 2003, Grémillet et al. 2004). As seabirds are not territorial at 
sea, indirect competition is thought to be a mediating factor (Furness \& Birkhead 1984, Lewis et al. 2001). A hinterland model has been proposed (Cairns 1989), but this predicts absolute partitioning, whereas tracking data have shown partial partitioning, if any (Stahl \& Sagar 2000, Huin 2002, Grémillet et al. 2004). This is probably because intraspecific competition intensity varies with conspecific density, and thus decreases as a continuous function of distance from neighboring colonies (Furness \& Birkhead 1984). While direct competition with conspecifics and other species is detrimental to foraging success, other interactions between these groups may be beneficial (e.g. the presence or behavior of other predators may indicate the location of prey, leading to local enhancement, Silverman et al. 2004; or network foraging, Au \& Pitman 1986). Multispecies feeding associations, e.g. between dolphins or tuna and seabirds, may even be cooperative (Wittenburger \& Hunt 1971). Few tracking studies have so far considered the response of pelagic seabirds to both competitors and habitat (Grémillet et al. 2004, Ford et al. 2007). However, this is now a realistic proposition since conspecifics from neighboring colonies and sympatric species from the same foraging guild can be tracked simultaneously.

\section{ANALYSES AND MODELS}

Early pelagic seabird tracking studies tended to describe habitat use qualitatively, often presenting either individual tracks (e.g. Weimerskirch et al. 1993, Prince et al. 1998) or the locations of a number of animals overlaid on maps of environmental variables (e.g. Cherel \& Weimerskirch 1995, Anderson et al. 1998). This was a pragmatic way of identifying likely macroscale preferences, such as those for neritic or oceanic waters (e.g. Huin 2002, Anderson et al. 2003). More recent analyses have tended to evolve from these approaches rather than from a theoretical base, and the emphasis on hypothesis testing using conventional statistical techniques has various drawbacks (McCarthy 2007). For example, ANOVA, Mann-Whitney tests and $t$-tests have been used to compare the amount of time spent by birds in regions that differed in bathymetry, SST, productivity and fishing effort (Waugh et al. 1999, Nel et al. 2000, Nel et al. 2002, Waugh \& Weimerskirch 2003, Petersen et al. 2008). A weakness of this approach is that habitat categories perceived by humans may have little biological meaning (Aarts et al. 2008). Consideration should be given to the mechanisms through which covariates are hypothesized or are known to affect spatial usage before deciding whether they should be treated as continuous or categorical (Hill \& Binford 2002). For example, it is known a priori that neritic and oceanic waters are dom- inated by different suites of oceanographic phenomena (e.g. seasonally mixed vs. permanently stratified waters), so it may be appropriate in some cases to bin depth into these categories. It is less clear why productivity, SST, etc., should be classified into different regimes, other than to facilitate the use of conventional statistical tests. Differences in habitat use among trip types, breeding stages, sex, year, populations and species have also been shown through a hypothesis testing approach, using chisquare tests, $t$-tests, ANOVA, generalized linear models (GLMs) and mixed-effects models (Hyrenbach et al. 2002, Nicholls et al. 2002, Phillips et al. 2004b, Pinaud et al. 2005, Rayner et al. 2008, Shaffer et al. 2009, this Theme Section).

Core areas of spatial usage are frequently identified using kernel density (KD) estimates (e.g. Wood et al. 2000, Hyrenbach et al. 2002). KD itself has been treated as a response variable (Awkerman et al. 2005), and spatial correlations between KD and environmental variables have been used to infer habitat associations (Rayner et al. 2008). Habitat association has also been tested by comparing mean productivity ( $\mathrm{chl}$ a) in areas used by birds to an empirical distribution of productivity randomly resampled across the birds' range (Gonzalez-Solis et al. 2007). Differences in behavior, such as the time spent searching or traveling, track straightness, FPT and flight speed with habitat have also been tested to identify which habitats are used more frequently for foraging (Weimerskirch et al. 1997b, Hyrenbach et al. 2002, Weimerskirch et al. 2002, Suryan et al. 2006, Pinaud \& Weimerskirch 2007). Discriminant function analysis has been used to test which environmental covariates best predict behavioral state (Awkerman et al. 2005, Pinaud \& Weimerskirch 2007).

Most early studies treated individual locations as independent. This assumption is invalid because tracking devices collect many locations from one individual. As such, tracking data are increasingly analyzed using mixed-effects models, treating the individual bird as a random effect (e.g. Hyrenbach et al. 2002, Garthe et al. 2007a). Tracking data also violate assumptions of independence because they tend to be serially and sometimes spatially autocorrelated (Aarts et al. 2008). A rather severe way of dealing with this is to delete locations sequentially until independence is achieved (e.g. Swihart \& Slade 1985). A more economical approach would be to use spatiotemporally explicit techniques to model dependence due to autocorrelation (Dormann et al. 2007).

Methods often used to model the spatial usage of animals tracked in terrestrial environments, such as resource selection functions (RSF) (Manly et al. 2002), have not found wide application in pelagic studies. Indeed, to date, the habitat preference sensu Manly et 
al. (2002) of only one species of pelagic seabird has been quantified using individual movement data. Following Aebischer et al. (1993), Pinaud \& Weimerskirch (2005) used compositional analysis to compare habitats used by breeding Indian yellow-nosed albatrosses Thalassarche carteri to those available on a $20 \mathrm{~km}$ grid, weighting the availability of each cell as a function of colony distance to account for accessibility. Although the modeling of habitat preference using individual movement data is an active area of research, robust techniques are becoming widely available to ecologists, especially through the profusion of packages contributed to the R statistical computing project (e.g. Calenge 2006). Hence, there is a shift towards model selection and model averaging as a way of investigating habitat preference. Spatial usage models can be fitted to telemetry data at the level of the individual (reviewed by Patterson et al. 2008, Schick et al. 2008), or the population (reviewed by Moorcroft \& Barnett 2008). The key problems facing population-level modelers were discussed by Aarts et al. (2008) and Matthiopoulos \& Aarts (2009). In addition to issues already mentioned, they include nonlinearity in animal response to the environment, which is increasingly being addressed using generalized additive models (GAMs) (Guisan et al. 2002). Aarts et al. (2008) used mixedeffects GAMs to model the spatial usage of satellitetracked grey seals Halichoerus grypus as a function of habitat accessibility and preference. We have recently extended this approach to model the spatial usage of breeding black-browed albatrosses Thalassarche melanophrris as a function of habitat accessibility, preference and conspecific competition (Fig. 3; Wakefield et al. unpubl.). A number of similar techniques may also be used to model habitat use with individual movement data (reviewed by Matthiopoulos \& Aarts 2009). For example, ecological niche factor analysis has recently been used to model the spatial distribution of feeding northern gannets Morus bassanus (Skov et al. 2008). Although this technique is useful for identifying the environmental covariates to which birds respond, it provides no information on the shape of that response.

Increasingly, the behavioral responses of animals to their environment are being modeled at the individual level using SSMs (Jonsen et al. 2003, Morales et al. 2004, Eckert et al. 2008), and it is hoped that SSMs will ultimately allow population-level inferences to be drawn (Patterson \& Fraser 2000). SSMs are able to account for uncertainty in location errors - a feature which makes them of particular utility in modeling geolocator data (Royer et al. 2005). Recently, Schick et al. (2008) proposed incorporating RSFs and SSMs in a hierarchical Bayesian framework, effectively modeling a moving animal's behavioral response to a habitat map centered on the present location (see also Christ et al.
2008). Although such techniques are complex and computationally demanding, they are becoming more practicable and seem likely to play an important role in quantifying pelagic seabird habitat preferences.

Many other statistical techniques are also available for analyzing animal movement and spatial usage (see Turchin 1998, Kenward 2001, Scott et al. 2002). However, it should be cautioned that animal movement models and theory were historically developed for taxa that are very different from pelagic seabirds. For example, much effort has gone into modeling the spatial usage of endangered ungulates (Mladenoff et al. 1999, Johnson et al. 2002, Morales et al. 2005). However, unlike pelagic seabirds, these animals are not constrained to return to a central place, are slow moving and travel over a solid medium. Wide-ranging, higher marine predators, such as penguins, pinnipeds, fish and turtles, which have also been the subject of recent modeling studies (Jonsen et al. 2003, Royer et al. 2005, Jonsen et al. 2007, Aarts et al. 2008, Eckert et al. 2008, Gurarie et al. 2009) are more similar to pelagic seabirds in that they travel through a fluid medium. This may have important consequences for the interpretation of observed movement patterns (Campagna et al. 2006, Gaspar et al. 2006, Cotte et al. 2007). However, unlike these animals, pelagic seabirds are almost unique in that they travel in one fluid medium (the atmosphere) and forage in another (the sea) - a trait that makes relating their movement to their environment somewhat more complex. Similarly, although there are many empirical and theoretical models of central place foragers, most of these relate to terrestrial taxa such as colonial insects, rodents and terrestrial birds (e.g. Giraldeau et al. 1994, Dukas \& EdelsteinKeshet 1998, Brown \& Gordon 2000, Olsson et al. 2008). Unlike the majority of pelagic seabirds, these groups usually suffer significant predation risk and may be territorial. In short, not all movement models are appropriate to pelagic seabirds. However, understanding the reasons for this is illuminating in itself.

\section{FUTURE DIRECTIONS}

Over the past $25 \mathrm{yr}$, tracking technology has greatly advanced our understanding of the interactions between pelagic seabirds and their environment (Wilson et al. 2002, Burger \& Shaffer 2008, Phillips et al. 2008). Although the habitat use of many species has been described and quantified, only one tracking study has to date formally compared habitat usage to availability, and thus quantified habitat preference (Pinaud et al. 2005). This has partly been due to a lack of theoretically grounded statistical methods for treating individual movement data that nonspecialists are able to 


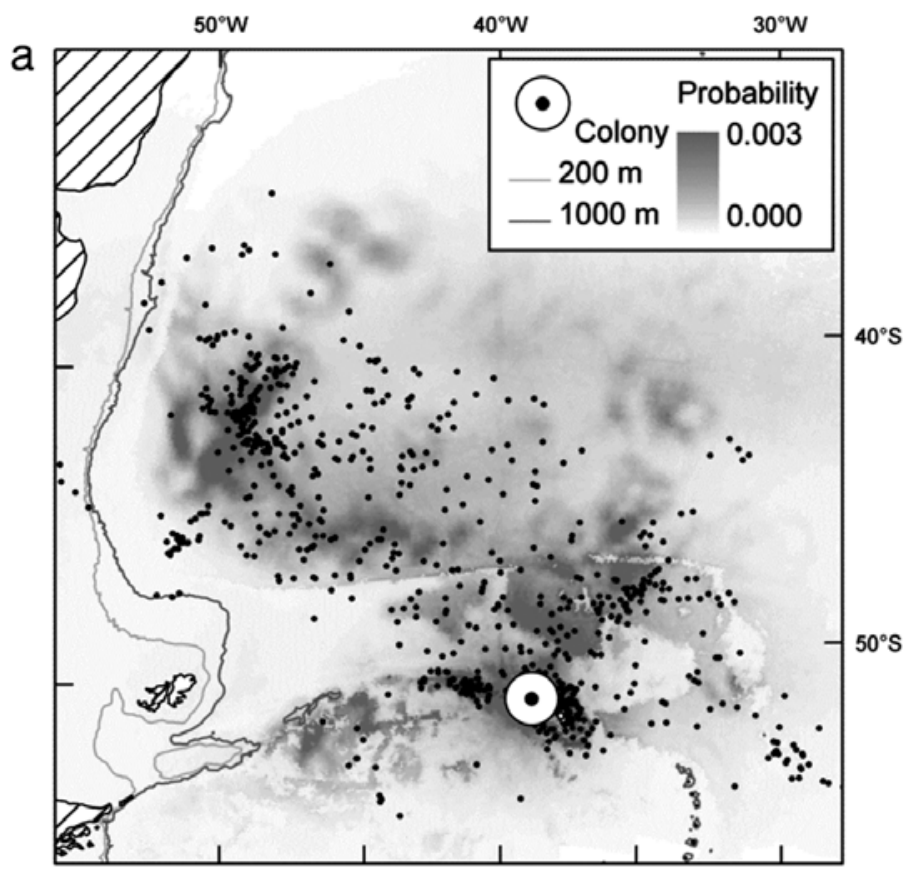

Fig. 3. Mixed-effects generalized additive models of black-browed albatross spatial usage. The response variable was presence-absence, where presence locations comprised of ARGOS fixes and pseudo-absence locations were quasi-randomly generated at a rate inversely proportional to colony distance. (a) Predicted probability of presence of 17 birds tracked from South Georgia during incubation vs. actual usage $(\bullet)$. Spatial usage was modeled as a function of habitat accessibility and preference. Explanatory covariates were depth, depth slope, sea surface temperature (SST), eddy kinetic energy (EKE) and colony distance. Birds from this population preferred to forage in local neritic waters and distant areas of highly dynamic mesoscale variability, characterized by high EKE. (b) and (c) Density of birds from adjacent colonies in the Kerguelen archipelago, estimated with a spatial usage model fitted to data for 54 birds tracked from 5 colonies throughout the species' range. This model included distance to other colonies as an additional explanatory covariate, and shows how intraspecific competition, habitat preference and accessibility can give rise to the partial segregation of foraging zones along colony lines (from Wakefield et al. unpubl., see also Aarts et al. 2008)
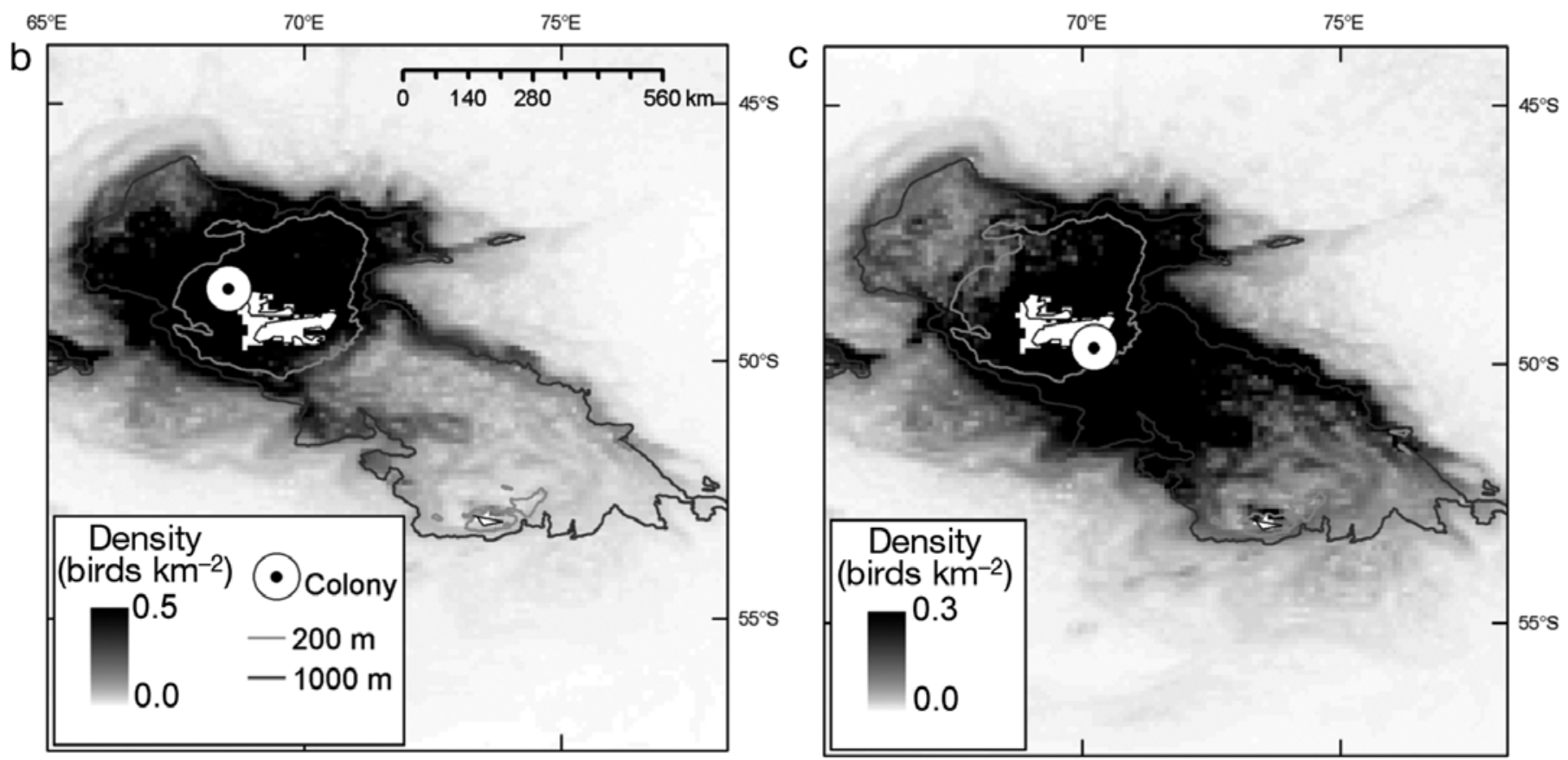

implement. We suggest that this is no longer an impediment, and that tracking data for pelagic seabirds can be used to address a wider range of ecological questions. For example, by quantifying the effects of habitat preference and accessibility on spatial usage (Fig. 3), the effects of central place constraint and competition on populations can be better understood. Ultimately, this approach may allow the prediction of carrying capacities for pelagic seabird populations (Beck et al. 2006, Jennings et al. 2008). At present, it is feasi-

ble to implement models at the population level using empirical, Eulerian approaches such as GLMs and GAMs (Moorcroft \& Barnett 2008). Although it is possible to account for individual variation and serial autocorrelation using a mixed-effects framework with an autoregressive structure (Pinheiro \& Bates 2000, Wood 2006), analyses of fewer data from many animals are more powerful than those of many data from a few animals, even if this makes data collection logistically more demanding. 
Individual-level SSMs are advancing rapidly (Patterson \& Fraser 2000, Schick et al. 2008). SSMs are particularly useful for analyzing geolocator data, which are prone to large errors, and may exploit the behavioral information inherent in individual movement data more fully. Inferences of behavioral states, such as ARS, which are based on theoretical predictions of animal movement, should also be validated more directly, e.g. by using auxiliary loggers to indicate when an animal actually ingests prey (Catry et al. 2004b, Austin et al. 2006, Weimerskirch et al. 2007). Such studies would greatly enhance the utility of high temporal resolution data collected using GPS loggers, which are increasingly replacing PTTs as the tracking instrument of choice.

To date, the majority of tracking studies of pelagic seabirds have concentrated on large species during breeding. The continued miniaturization of tracking devices, and particularly of geolocators, means that very small, and hitherto little-known species such as the storm petrels (Hydrobatidae), may soon be targeted. Annual and multi-year deployments of geolocators and even GPS units are already garnering data on nonbreeding and immature birds, which may represent up to half of the total number of some species (Shaffer et al. 2006, Weimerskirch et al. 2006a, Bugoni et al. 2009). Differences in habitat use have been detected between species (González-Solis et al. 2000a, Phillips et al. 2004b, Pinaud \& Weimerskirch 2007), breeding stages (Weimerskirch et al. 1993, Phillips et al. 2004b), sexes (González-Solis et al. 2000b, Phillips et al. 2004b, Weimerskirch et al. 2006b) and age groups (Weimerskirch et al. 2006a). Hence, it would be informative to include individual characteristics in habitat preference models (Aarts et al. 2008). Similarly, as habitat use may vary inter-annually (Xavier et al. 2003, Pinaud et al. 2005), and between populations (González-Solis et al. 2000a, Grémillet et al. 2004, Rayner et al. 2008), potential plasticity in habitat preferences should be considered, and if possible incorporated into analyses before drawing far-reaching conclusions.

Although the response of pelagic seabirds to certain phenomena (e.g. small-scale turbulence and long-term climate fluctuations) are not presently detectable, improvements in tracking and remote sensing technologies are widening the observable window on pelagic habitats (Fig. 1). Responses to shorter-term climate fluctuations (e.g. ENSO events and even regime shifts) may soon be measurable by tracking birds from the same populations repeatedly over consecutive years and decades. Most studies on pelagic seabirds to date have combined satellite tracking with medium resolution environmental data (e.g. SST, chl $a$, sea surface height anomalies or SSHa) to examine habitat prefer- ences at scales of days to weeks and 100s to 10000 s of $\mathrm{km}$. At macro- to megascales, pelagic areas of higher than average productivity are recognized as hotspots for seabird abundance (Worm et al. 2005), and there is increasing evidence for definable habitat preferences at the mesoscale (e.g. for eddies, upwelling and shelfbreak fronts). At finer scales, it has been contended that the distribution of mobile vertebrates is uncoupled from the underlying physical structure of their environment (Pinaud \& Weimerskirch 2005). However, ship-based studies often find that seabirds aggregate at fine- to coarse-scale features, including fronts (e.g. Hunt 1991, Skov \& Prins 2001). Why such associations have not been apparent in tracking studies may simply be because the resolution of tracking and remotely sensed environmental data was hitherto insufficient to detect them. However, at coarse scales, SAR imagery now reveals processes that are not observable using conventional remote sensing techniques. Furthermore, the mixed layer depth can now be predicted with remotely sensed data (Zawada et al. 2005), and further investigations of its influence on habitat use would be profitable (Spear et al. 2001, Vilchis et al. 2006).

Our increasing ability to understand, and therefore predict, individual- and population-level spatial usage is timely, since a large proportion of pelagic seabirds (especially albatrosses and large petrels) is threatened by incidental mortality in longline and trawl fisheries (Tuck et al. 2003, Butchart et al. 2004, Phillips et al. 2006). Hence, knowledge of their habitat use and preferences will be critical for the monitoring and mitigation of these and other anthropogenic impacts on the marine environment, as well as for addressing wider ecological questions.

Acknowledgements. We thank 4 anonymous reviewers who provided helpful feedback on an early draft of this review. This study was conducted while the first author was in receipt of a UK Natural Environment Research Council CASE studentship (NER/S/A/2005/13648).

\section{LITERATURE CITED}

Aarts G, MacKenzie M, McConnell B, Fedak M, Matthiopoulos J (2008) Estimating space-use and habitat preference from wildlife telemetry data. Ecography 31:140-160

- Abbott MR, Barksdale B (1991) Phytoplankton pigment patterns and wind forcing off central California. J Geophys Res C 96:14649-14667

Abraham ER (1998) The generation of plankton patchiness by turbulent stirring. Nature 391:577-580

Adler FR, Gordon DM (2003) Optimization, conflict, and nonoverlapping foraging ranges in ants. Am Nat 162: 529-543

Aebischer NJ, Robertson PA, Kenward RE (1993) Compositional analysis of habitat use from animal radio-tracking data. Ecology 74:1313-1325 
Ainley DG, Ford RG, Brown ED, Suryan RM, Irons DB (2003) Prey resources, competition, and geographic structure of kittiwake colonies in Prince William Sound. Ecology 84: 709-723

Aksenov Y, Coward AC (2001) The Arctic Ocean circulation as simulated in a very high-resolution global ocean model (OCCAM). Ann Glaciol 33:567-576

Alerstam T, Gudmundsson GA, Larsson B (1993) Flight tracks and speeds of Antarctic and Atlantic seabirds: radar and optical measurements. Philos Trans R Soc Lond B 340:55-67

Anderson DJ, Schwandt AJ, Douglas HD (1998) Foraging ranges of waved albatrosses in the eastern tropical Pacific Ocean. In: Robertson G, Gales R (eds) Albatross biology and conservation. Surrey Beatty \& Sons, Chipping Norton, NSW, p 180-185

$>$ Anderson DJ, Huyvaert KP, Wood DR, Gillikin CL, Frost BJ, Mouritsen H (2003) At-sea distribution of waved albatrosses and the Galapagos Marine Reserve. Biol Conserv 110: $367-373$

Ashmole NP (1963) The regulation of numbers of tropical oceanic birds. Ibis 103b:458-473

Ashmole NP (1971) Sea bird ecology and the marine environment. In: Farner DS, King JR, Parkes KC (eds) Avian biology, Vol 1. Academic Press, New York, p 223-286

Au DWK, Pitman RL (1986) Seabird interactions with dolphins and tuna in the eastern tropical Pacific. Condor 88: 304-317

Austin D, Bowen WD, McMillan JI, Iverson SJ (2006) Linking movement, diving, and habitat to foraging success in a large marine predator. Ecology 87:3095-3108

> Awkerman JA, Fukuda A, Higuchi H, Anderson DJ (2005) Foraging activity and submesoscale habitat use of waved albatrosses Phoebastria irrorata during chick-brooding period. Mar Ecol Prog Ser 291:289-300

Ballance LT (2008) Understanding seabirds at sea: why and how? Mar Ornithol 35:127-135

> Beck JL, Peek JM, Strand EK (2006) Estimates of elk summer range nutritional carrying capacity constrained by probabilities of habitat selection. J Wildl Manage 70:283-294

Begg GS, Reid JB (1997) Spatial variation in seabird density at a shallow sea tidal mixing front in the Irish Sea. ICES J Mar Sci 54:552-565

Begon M, Townsend CR, Harper JL (2006) Ecology: from individuals to ecosystems. Blackwell Publishing, Malden, MA

Behrenfeld MJ, Falkowski PG (1997) A consumer's guide to phytoplankton primary productivity models. Limnol Oceanogr 42:1479-1491

- Bertrand A, Gerlotto F, Bertrand S, Gutierrez M and others (2008) Schooling behaviour and environmental forcing in relation to anchoveta distribution: an analysis across multiple spatial scales. Prog Oceanogr 79:264-277

BirdLife International (2004) Tracking ocean wanderers: the global distribution of albatrosses and petrels. Results from the Global Procellariiform Tracking Workshop, 1-5 Sept 2003, Gordon's Bay, South Africa. BirdLife International, Cambridge, UK

Biuw M, Boehme L, Guinet C, Hindell M and others (2007) Variations in behavior and condition of a Southern Ocean top predator in relation to in situ oceanographic conditions. Proc Natl Acad Sci USA 104:13705-13710

Boehme L, Meredith MP, Thorpe SE, Biuw M, Fedak M (2008) Antarctic Circumpolar Current frontal system in the South Atlantic: monitoring using merged Argo and animalborne sensor data. J Geophys Res C 113:C09012, doi:10. 1029/2007JC004647

Boersma PD, Rebstock GA (2009) Foraging distance affects reproductive success in Magellanic penguins. Mar Ecol
Prog Ser 375:263-275

Bost CA, Thiebot JB, Pinaud D, Cherel Y, Trathan PN (2009) Where do penguins go during the inter-breeding period? Using geolocation to track the winter dispersion of the macaroni penguin. Biol Lett, 5(4):473-476, preprint, doi: 10.1098/rsbl.2009.0265

> Bradshaw CJA, Sims DW, Hays GC (2007) Measurement error causes scale-dependent threshold erosion of biological signals in animal movement data. Ecol Appl 17:628-638

Britten MW, Kennedy PL, Ambrose S (1999) Performance and accuracy evaluation of small satellite transmitters. J Wildl Manage 63:1349-1358

Brothers N, Gales R, Hedd A, Robertson G (1998) Foraging movements of the shy albatross Diomedea cauta breeding in Australia: implications for interactions with longline fisheries. Ibis 140:446-457

Brown MJF, Gordon DM (2000) How resources and encounters affect the distribution of foraging activity in a seedharvesting ant. Behav Ecol Sociobiol 47:195-203

Bugoni L, D'Alba L, Furness RW (2009) Marine habitat use of wintering spectacled petrels Procellaria conspicillata, and overlap with longline fishery. Mar Ecol Prog Ser 374: 273-285

> Burger AE, Shaffer SA (2008) Application of tracking and data-logging technology in research and conservation of seabirds. Auk 125:253-264

> Butchart SHM, Stattersfield AJ, Bennun LA, Shutes SM and others (2004) Measuring global trends in the status of biodiversity: red list indices for birds. PLoS Biol 2:e383

> Cairns DK (1989) The regulation of seabird colony size: a hinterland model. Am Nat 134:141-146

> Calenge C (2006) The package 'adehabitat' for the R software: a tool for the analysis of space and habitat use by animals. Ecol Model 197:516-519

Campagna C, Piola AR, Marin MR, Lewis M, Fernandez T (2006) Southern elephant seal trajectories, fronts and eddies in the Brazil/Malvinas Confluence. Deep-Sea Res I 53:1907-1924

> Catry P, Phillips RA, Croxall JP (2004a) Sustained fast travel by a gray-headed albatross (Thalassarche chrysostoma) riding an Antarctic storm. Auk 121:1208-1213

Catry P, Phillips RA, Phalan B, Silk JRD, Croxall JP (2004b) Foraging strategies of grey-headed albatrosses Thalassarche chrysostoma: integration of movements, activity and feeding events. Mar Ecol Prog Ser 280:261-273

Cherel Y, Klages NTW (1998) A review of the food of albatrosses. In: Robertson G, Gales R (eds) Albatross biology and conservation. Surrey Beatty \& Sons, Chipping Norton, NSW, p 113-136

Cherel Y, Weimerskirch H (1995) Seabirds as indicators of marine resources: black-browed albatrosses feeding on ommastrephid squids in Kerguelen waters. Mar Ecol Prog Ser 129:295-300

- Cherel Y, Phillips RA, Hobson KA, McGill R (2006) Stable isotope evidence of diverse species-specific and individual wintering strategies in seabirds. Biol Lett 2:301-303

Christ A, Hoef J, Zimmerman D (2008) An animal movement model incorporating home range and habitat selection. Environ Ecol Stat 15:27-38

Clarke A (2003) Costs and consequences of evolutionary temperature adaptation. Trends Ecol Evol 18:573-581

Costa DP (1991) Reproductive and foraging energetics of high-latitude penguins, albatrosses and pinnipeds: implications for life history patterns. Am Zool 31:111-130

Cotte C, Park YH, Guinet C, Bost CA (2007) Movements of foraging king penguins through marine mesoscale eddies. Proc R Soc Lond B 274:2385-2391 
Croll DA, Marinovic B, Benson S, Chavez FP, Black N, Ternullo R, Tershy BR (2005) From wind to whales: trophic links in a coastal upwelling system. Mar Ecol Prog Ser 289:117-130

Croxall JP, Prince ED (1980) Food, feeding ecology and ecological segregation of seabirds at South Georgia. Biol J Linn Soc 14:103-131

Daunt F, Peters G, Scott B, Grémillet D, Wanless S (2003) Rapid-response recorders reveal interplay between marine physics and seabird behaviour. Mar Ecol Prog Ser 255: 283-288

Dormann CF, McPherson JM, Araujo MB, Bivand R and others (2007) Methods to account for spatial autocorrelation in the analysis of species distributional data: a review. Ecography 30:609-628

$>$ Dubois DM (1975) A model of patchiness for prey-predator plankton populations. Ecol Model 1:67-80

Ducet N, Le Traon PY, Reverdin G (2000) Global high-resolution mapping of ocean circulation from TOPEX/Poseidon and ERS-1 and -2. J Geophys Res C 105:19477-19498

Dukas R, Edelstein-Keshet L (1998) The spatial distribution of colonial food provisioners. J Theor Biol 190:121-134

Eckert SA, Moore JE, Dunn DC, van Buiten RS, Eckert KL, Halpin PN (2008) Modeling loggerhead turtle movement in the Mediterranean: importance of body size and oceanography. Ecol Appl 18:290-308

Eldevik T, Dysthe KB (2002) Spiral eddies. J Phys Oceanogr 32: 851-869

Falk K, Moller S (1995) Satellite tracking of high-Arctic northern fulmars. Polar Biol 15:495-502

Fauchald P (1999) Foraging in a hierarchical patch system. Am Nat 153:603-613

> Fauchald P, Tveraa T (2003) Using first-passage time in the analysis of area-restricted search and habitat selection. Ecology 84:282-288

Fauchald P, Erikstad KE, Skarsfjord H (2000) Scale-dependent predator-prey interactions: the hierarchical spatial distribution of seabirds and prey. Ecology 81:773-783

Felicisimo AM, Munoz J, Gonzalez-Solis J (2008) Ocean surface winds drive dynamics of transoceanic aerial movements. PLoS One 3:e2928

> Fernandez P, Anderson DJ (2000) Nocturnal and diurnal foraging activity of Hawaiian albatrosses detected with a new immersion monitor. Condor 102:577-584

Fernandez P, Anderson DJ, Sievert PR, Huyvaert K (2001) Foraging destinations of three low-latitude albatross (Phoebastria) species. J Zool 254:391-404

Folt CL, Burns CW (1999) Biological drivers of zooplankton patchiness. Trends Ecol Evol 14:300-305

Ford RG, Ainley DG, Brown ED, Suryan RM, Irons DB (2007) A spatially explicit optimal foraging model of blacklegged Kittiwake behavior based on prey density, travel distances, and colony size. Ecol Model 204:335-348

Freeman AND, Nicholls DG, Wilson KJ, Bartle JA (1997) Radio- and satellite-tracking Westland petrels Procellaria westlandica. Mar Ornithol 25:31-36

Friedlaender AS, Halpin PN, Qian SS, Lawson GL, Wiebe PH, Thiele D, Read AJ (2006) Whale distribution in relation to prey abundance and oceanographic processes in shelf waters of the Western Antarctic Peninsula. Mar Ecol Prog Ser 317:297-310

Fukuda A, Miwa K, Hirano E, Suzuki M and others (2004) BGDL-II-A GPS data logger for birds. Mem Natl Inst Polar Res (Spec Issue) 58:234-245

$>$ Furness RW, Birkhead TR (1984) Seabird colony distributions suggest competition for food supplies during the breeding season. Nature 311:655-656

Garcia D, Ortiz-Pulido R (2004) Patterns of resource tracking by avian frugivores at multiple spatial scales: two case studies on discordance among scales. Ecography 27:187-196

Garthe S, Montevecchi WA, Chapdelaine G, Rail JF, Hedd A (2007a) Contrasting foraging tactics by northern gannets (Sula bassana) breeding in different oceanographic domains with different prey fields. Mar Biol 151:687-694

Garthe S, Montevecchi WA, Davoren GK (2007b) Flight destinations and foraging behaviour of northern gannets (Sula bassana) preying on a small forage fish in a low-Arctic ecosystem. Deep-Sea Res II 54:311-320

- Gaspar P, Georges JY, Fossette S, Lenoble A, Ferraroli S, Le Maho Y (2006) Marine animal behaviour: neglecting ocean currents can lead us up the wrong track. Proc R Soc Lond B 273:2697-2702

Gens R (2008) Oceanographic applications of SAR remote sensing. GISci Remote Sens 45:275-305

Giraldeau LA, Kramer DL, Deslandes I, Lair H (1994) The effect of competitors and distance on central place foraging eastern chipmunks, Tamias striatus. Anim Behav 47: $621-632$

> González-Solis J, Croxall JP, Wood AG (2000a) Foraging partitioning between giant petrels Macronectes spp. and its relationship with breeding population changes at Bird Island, South Georgia. Mar Ecol Prog Ser 204:279-288

> González-Solis J, Croxall JP, Wood AG (2000b) Sexual dimorphism and sexual segregation in foraging strategies of northern giant petrels, Macronectes halli, during incubation. Oikos 90:390-398

> Gonzalez-Solis J, Croxall JP, Oro D, Ruiz X (2007) Transequatorial migration and mixing in the wintering areas of a pelagic seabird. Front Ecol Environ 5:297-301

Grémillet D, Dell'Omo G, Ryan PG, Peters G, Ropert-Coudert Y, Weeks SJ (2004) Offshore diplomacy, or how seabirds mitigate intra-specific competition: a case study based on GPS tracking of Cape gannets from neighbouring colonies. Mar Ecol Prog Ser 268:265-279

- Guilford TC, Meade J, Freeman R, Biro D and others (2008) GPS tracking of the foraging movements of Manx shearwaters Puffinus puffinus breeding on Skomer Island, Wales. Ibis 150:462-473

Guilford T, Meade J, Willis J, Phillips RA and others (2009) Migration and stopover in a small pelagic seabird, the Manx shearwater Puffinus puffinus: insights from machine learning. Proc R Soc Lond B 276:1215-1223

> Guisan A, Edwards TC, Hastie T (2002) Generalized linear and generalized additive models in studies of species distributions: setting the scene. Ecol Model 157:89-100

> Gurarie E, Andrews RD, Laidre KL (2009) A novel method for identifying behavioural changes in animal movement data. Ecol Lett 12:395-408

Hall LS, Krausman PR, Morrison ML (1997) The habitat concept and a plea for standard terminology. Wildl Soc Bull 25:173-182

- Hamer KC, Phillips RA, Wanless S, Harris MP, Wood AG (2000) Foraging ranges, diets and feeding locations of gannets Morus bassanus in the North Sea: evidence from satellite telemetry. Mar Ecol Prog Ser 200:257-264

Haury LR, McGowan JA, Wiebe PH (1977) Patterns and processes in the time-space scales of plankton distributions. In: Steele JH (ed) Spatial pattern in plankton communities. Premium Press, New York, p 470

Hill KE, Binford MW (2002) The role of category definition in habitat models: practical and logical limitations of using Boolean, indexed, probabilistic and fuzzy categories. In: Scott JM, Heglund PJ, Morrison ML (eds) Predicting species occurrences: issues of accuracy and scale. Island Press, Washington, DC, p 97-106 
Hoefer CJ (2000) Marine bird attraction to thermal fronts in the California Current system. Condor 102:423-427

Horne JS, Garton EO, Krone SM, Lewis JS (2007) Analyzing animal movements using Brownian bridges. Ecology 88: 2354-2363

Huin N (2002) Foraging distribution of the black-browed albatross, Thalassarche melanophris, breeding in the Falkland Islands. Aquat Conserv: Mar Freshw Ecosyst 12:89-99

Hunt GL (1991) Occurrence of polar seabirds at sea in relation to prey concentrations and oceanographic factors. Polar Res 10:553-559

Hunt GL, Mehlum F, Russell RW, Irons D, Decker MB, Becker PH (1999) Physical processes, prey abundance, and the foraging ecology of seabirds. In: Adams NJ, Slotow R (eds) Proc 22nd Intl Ornithological Congr. BirdLife South Africa, Durban, Johannesburg, p 2040-2056

Hyrenbach KD, Dotson RC (2003) Assessing the susceptibility of female black-footed albatross (Phoebastria nigripes) to longline fisheries during their post-breeding dispersal: an integrated approach. Biol Conserv 112:391-404

> Hyrenbach KD, Veit RR (2003) Ocean warming and seabird communities of the southern California Current System (1987-98): response at multiple temporal scales. Deep-Sea Res II 50:2537-2565

> Hyrenbach KD, Fernández P, Anderson DJ (2002) Oceanographic habitats of two sympatric North Pacific albatrosses during the breeding season. Mar Ecol Prog Ser 233: 283-301

Jahncke J, Coyle KO, Zeeman SI, Kachel NB, Hunt GL Jr (2005) Distribution of foraging shearwaters relative to inner front of SE Bering Sea. Mar Ecol Prog Ser 305:219-233

> Jennings S, Melin F, Blanchard JL, Forster RM, Dulvy NK, Wilson RW (2008) Global-scale predictions of community and ecosystem properties from simple ecological theory. Proc R Soc Lond B 275:1375-1383

> Jenouvrier S, Weimerskirch H, Barbraud C, Park YH, Cazelles B (2005) Evidence of a shift in the cyclicity of Antarctic seabird dynamics linked to climate. Proc R Soc Lond B 272:887-895

> Johnson CJ, Parker KL, Heard DC, Gillingham MP (2002) Movement parameters of ungulates and scale-specific responses to the environment. J Anim Ecol 71:225-235

Jonsen ID, Myers RA, Flemming JM (2003) Meta-analysis of animal movement using state-space models. Ecology 84 : 3055-3063

> Jonsen ID, Myers RA, James MC (2007) Identifying leatherback turtle foraging behaviour from satellite telemetry using a switching state-space model. Mar Ecol Prog Ser 337:255-264

Jouventin P, Weimerskirch H (1990) Satellite tracking of wandering albatrosses. Nature 343:746-748

Kaiser MJ, Attrill MJ, Jennings S, Thomas DN and others (2005) Marine ecology: processes, systems and impacts. Oxford University Press, Oxford

Kareiva P, Odell G (1987) Swarms of predators exhibit preytaxis if individual predators use area-restricted search. Am Nat 130:233-270

Kenward RE (2001) A manual for wildlife radio tagging. Academic Press, San Diego, CA

Kotliar NB, Wiens JA (1990) Multiple scales of patchiness and patch structure: a hierarchical framework for the study of heterogeneity. Oikos 59:253-260

Lack D (1954) The natural regulation of animal numbers. Oxford University Press, Oxford

Lack D (1968) Ecological adaptations for breeding in birds. Methuen, London

Laidre KL, Heide-Jorgensen MP, Nyeland J, Mosbech A,
Boertmann D (2008) Latitudinal gradients in sea ice and primary production determine Arctic seabird colony size in Greenland. Proc R Soc Lond B 275:2695-2702

$>$ Levin SA (1992) The problem of pattern and scale in ecology. Ecology 73:1943-1967

Levin SA (1993) Patchiness in marine and terrestrial systems: from individuals to populations. Royal Society discussion meeting: generalizing across marine and terrestrial ecology. Royal Society of London, p 99-103

Lewis S, Sherratt TN, Hamer KC, Wanless S (2001) Evidence of intra-specific competition for food in a pelagic seabird. Nature 412:816-819

Lewis S, Elston DA, Daunt F, Cheney B, Thompson PM (2009) Effects of extrinsic and intrinsic factors on breeding success in a long lived seabird. Oikos 118:521-528

> Lima SL, Zollner PA (1996) Towards a behavioral ecology of ecological landscapes. Trends Ecol Evol 11:131-135

> Littaye A, Gannier A, Laran S, Wilson JPF (2004) The relationship between summer aggregation of fin whales and satellite-derived environmental conditions in the northwestern Mediterranean Sea. Remote Sens Environ 90:44-52

Longhurst AL (1998) Ecological geography of the sea. Academic Press, San Diego, CA

> Louzao M, Hyrenbach KD, Arcos JM, Abello P, De Sola LG, Oro D (2006) Oceanographic habitat of an endangered Mediterranean procellariiform: implications for marine protected areas. Ecol Appl 16:1683-1695

Lutjeharms JRE, Walters NM, Allanson BR (1985) Oceanic frontal systems and biological enhancement. In: Siegfried WR, Condy PR, Laws RM (eds) Antarctic nutrient cycles and food webs. Springer-Verlag, Berlin

> Magalhães MC, Santos RS, Hamer KC (2008) Dual-foraging of Cory's shearwaters in the Azores: feeding locations, behaviour at sea and implications for food provisioning of chicks. Mar Ecol Prog Ser 359:283-293

Manly BF, McDonald L, Thomas DL, McDonald TL, Erickson WP (2002) Resource selection by animals. Statistical design and analysis for field studies. Springer, Berlin

Mann KH, Lazier JRN (2006) Dynamics of marine ecosystems. Blackwell Publishing, Malden, MA

Martin S (2004) An introduction to ocean remote sensing. Cambridge University Press, Cambridge

Matthiopoulos J (2003) The use of space by animals as a function of accessibility and preference. Ecol Model 159: $239-268$

Matthiopoulos J, Aarts G (2009) The spatial analysis of marine mammal abundance. In: Boyd IL, Bowen D, Iverson SJ (eds) Marine mammal science: a handbook of techniques. Oxford University Press, Oxford

McCarthy MA (2007) Bayesian methods for ecology. Cambridge University Press, Cambridge

McConnell B, Fedak M, Burton HR, Engelhard GH, Reijnders PJH (2002) Movements and foraging areas of naive, recently weaned southern elephant seal pups. J Anim Ecol 71:65-78

McGillicuddy DJ, Anderson LA, Bates NR, Bibby T and others (2007) Eddy/wind interactions stimulate extraordinary mid-ocean plankton blooms. Science 316:1021-1026

> Miller P (2004) Multi-spectral front maps for automatic detection of ocean colour features from SeaWiFS. Int J Remote Sens 25:1437-1442

> Mladenoff DJ, Sickley TA, Wydeven AP (1999) Predicting gray wolf landscape recolonization: logistic regression models vs. new field data. Ecol Appl 9:37-44

Moorcroft PR, Barnett A (2008) Mechanistic home range models and resource selection analysis: a reconciliation and unification. Ecology 89:1112-1119 
Moore JK, Abbott MR, Richman JG (1999) Location and dynamics of the Antarctic polar front from satellite sea surface temperature data. J Geophys Res C 104:3059-3073

Morales JM, Haydon DT, Frair J, Holsiner KE, Fryxell JM (2004) Extracting more out of relocation data: building movement models as mixtures of random walks. Ecology 85:2436-2445

Morales JM, Fortin D, Frair JL, Merrill EH (2005) Adaptive models for large herbivore movements in heterogeneous landscapes. Landscape Ecol 20:301-316

Murphy EJ, Thorpe SE, Watkins JL, Hewitt R (2004) Modeling the krill transport pathways in the Scotia Sea: spatial and environmental connections generating the seasonal distribution of krill. Deep-Sea Res II 51:1435-1456

Murray MD, Nicholls DG, Butcher E, Moors PJ (2002) How wandering albatrosses use weather systems to fly long distances. 1. An analytical method and its application to flights in the Tasman Sea. Emu 102:377-385

Murray MD, Nicholls DG, Butcher E, Moors PJ, Walker K, Elliott G (2003) How wandering albatrosses use weather systems to fly long distances. 3. The contributions of Antarctic LOWS to eastward, southward and northward flight. Emu 103:111-120

Nams VO (2005) Using animal movement paths to measure response to spatial scale. Oecologia 143:179-188

Nel DC, Nel JL, Ryan PG, Klages NTW, Wilson RP, Robertson G (2000) Foraging ecology of grey-headed mollymawks at Marion Island, southern Indian Ocean, in relation to longline fishing activity. Biol Conserv 96:219-231

> Nel DC, Lutjeharms JRE, Pakhomov EA, Ansorge IJ, Ryan PG, Klages NTW (2001) Exploitation of mesoscale oceanographic features by grey-headed albatross Thalassarche chrysostoma in the southern Indian Ocean. Mar Ecol Prog Ser 217:15-26

Nel DC, Ryan PG, Nel JL, Klages NTW, Wilson RP, Robertson G, Tuck GN (2002) Foraging interactions between wandering albatrosses Diomedea exulans breeding on Marion Island and long-line fisheries in the southern Indian Ocean. Ibis 144:E141-E154

Nicholls DG, Robertson CJR, Prince PA, Murray MD, Walker KJ, Elliott GP (2002) Foraging niches of three Diomedea albatrosses. Mar Ecol Prog Ser 231:269-277

Nicholls D, Robertson CJR, Murray MD (2007) Measuring accuracy and precision for CLS: ARGOS satellite telemetry. Notornis 54:137-157

> Oedekoven CS, Ainley DG, Spear LB (2001) Variable responses of seabirds to change in marine climate: California Current, 1985-1994. Mar Ecol Prog Ser 212:265-281

Olson SL, Hearty PJ (2003) Probable extirpation of a breeding colony of short-tailed albatross (Phoebastria albatrus) on Bermuda by Pleistocene sea-level rise. Proc Natl Acad Sci USA 100:12825-12829

> Olsson O, Brown JS, Helf KL (2008) A guide to central place effects in foraging. Theor Popul Biol 74:22-33

Orians GH, Pearson NE (1979) On the theory of central place foraging. In: Horn DJ, Stairs GR, Mitchelle RG (eds) Analysis of ecological systems. Ohio State University Press, Columbus, p 155-177

Pakhomov EA, McQuaid CD (1996) Distribution of surface zooplankton and seabirds across the Southern Ocean. Polar Biol 16:271-286

Parmelee DF, Parmelee JM, Fuller M (1985) Ornithological investigations at Palmer Station: the first long-distance tracking of seabirds by satellites. Antarct J US 20:162-163

Patterson DL, Fraser WR (2000) Foraging movements of southern giant petrels Macronectes giganteus on the Antarctic Peninsula: preliminary findings of a satellite-tracking study during the breeding season. In: Flint E, Swift K (eds) 2nd International Conference on the Biology and Conservation of Albatrosses and other Petrels. Honolulu, Hawaii, p 125-152

> Patterson TA, Thomas L, Wilcox C, Ovaskainen O, Matthiopoulos J (2008) State-space models of individual animal movement. Trends Ecol Evol 23:87-94

Pennycuick CJ (1982) The flight of petrels and albatrosses (Procellariiformes), observed in South Georgia and its vicinity. Philos Trans R Soc Lond B 300:75-106

Pennycuick CJ (1989) Bird flight performance: a practical calculation manual. Oxford University Press, Oxford

Perry RI, Harding GC, Loder JW, Tremblay MJ, Sinclair MM, Drinkwater KF (1993) Zooplankton distributions at the Georges Bank frontal system: retention or dispersion. Cont Shelf Res 13:357-383

Petersen SL, Phillips RA, Ryan PG, Underhill LG (2008) Albatross overlap with fisheries in the Benguela Upwelling System: implications for conservation and management. Endang Species Res 5:117-127

Phalan B, Phillips RA, Silk JRD, Afanasyev V and others (2007) Foraging behaviour of four albatross species by night and day. Mar Ecol Prog Ser 340:271-286

Phillips RA, Xavier JC, Croxall JP (2003) Effects of satellite transmitters on albatrosses and petrels. Auk 120:1082-1090

Phillips RA, Silk JRD, Croxall JP, Afanasyev V, Briggs DR (2004a) Accuracy of geolocation estimates for flying seabirds. Mar Ecol Prog Ser 266:265-272

> Phillips RA, Silk JRD, Phalan B, Catry P, Croxall JP (2004b) Seasonal sexual segregation in two Thalassarche albatross species: competitive exclusion, reproductive role specialization or foraging niche divergence? Proc R Soc Lond B 271:1283-1291

Phillips RA, Silk JRD, Croxall JP, Afanasyev V, Bennett VJ (2005) Summer distribution and migration of nonbreeding albatrosses: individual consistencies and implications for conservation. Ecology 86:2386-2396

Phillips RA, Silk JRD, Croxall JP, Afanasyev V (2006) Yearround distribution of white-chinned petrels from South Georgia: relationships with oceanography and fisheries. Biol Conserv 129:336-347

Phillips RA, Croxall JP, Silk JRD, Briggs DR (2008) Foraging ecology of albatrosses and petrels from South Georgia: two decades of insights from tracking technologies. Aquat Conserv: Mar Freshw Ecosyst 17:S6-S21

Pinaud D (2008) Quantifying search effort of moving animals at several spatial scales using first-passage time analysis: effect of the structure of environment and tracking systems. J Appl Ecol 45:91-99

Pinaud D, Weimerskirch H (2002) Ultimate and proximate factors affecting the breeding performance of a marine top-predator. Oikos 99:141-150

Pinaud D, Weimerskirch H (2005) Scale-dependent habitat use in a long-ranging central place predator. J Anim Ecol 74:852-863

> Pinaud D, Weimerskirch H (2007) At-sea distribution and scale-dependent foraging behaviour of petrels and albatrosses: a comparative study. J Anim Ecol 76:9-19

Pinaud D, Cherel Y, Weimerskirch H (2005) Effect of environmental variability on habitat selection, diet, provisioning behaviour and chick growth in yellow-nosed albatrosses. Mar Ecol Prog Ser 298:295-304

Pinheiro JC, Bates DM (2000) Mixed-effects models in S and S-PLUS. Springer-Verlag, New York

Prince PA, Wood AG, Barton T, Croxall JP (1992) Satellite tracking of wandering albatrosses (Diomedea exulans) in the South Atlantic. Antarct Sci 4:31-36 
Prince ED, Croxall JP, Trathan PN, Wood AG (1998) The pelagic distribution of South Georgia albatrosses and their relationship with fisheries. In: Robertson G, Gales R (eds) Albatross biology and conservation. Surrey Beatty \& Sons, Chipping Norton, NSW, p 137-167

Rayner MJ, Hauber ME, Clout MN, Seldon DS, Van Dijken S, Bury S, Phillips RA (2008) Foraging ecology of the Cook's petrel Pterodroma cookii during the austral breeding season: a comparison of its two populations. Mar Ecol Prog Ser 370:271-284

Redfern JV, Ferguson MC, Becker EA, Hyrenbach KD and others (2006) Techniques for cetacean-habitat modeling. Mar Ecol Prog Ser 310:271-295

Ribic CA, Ainley DG, Spear LB (1997) Scale-related seabirdenvironmental relationships in Pacific equatorial waters, with reference to El Niño-Southern Oscillation events. Mar Ecol Prog Ser 156:183-203

Robinson PW, Tremblay Y, Crocker DE, Kappes MA and others (2007) A comparison of indirect measures of feeding behaviour based on ARGOS tracking data. Deep-Sea Res II 54:356-368

Ropert-Coudert Y, Wilson RP (2005) Trends and perspectives in animal-attached remote sensing. Front Ecol Environ 3: 437-444

Royer F, Fromentin JM, Gaspar P (2005) A state-space model to derive bluefin tuna movement and habitat from archival tags. Oikos 109:473-484

Rudnick DL, Martin JP (2002) On the horizontal density ratio in the upper ocean. Dyn Atmos Oceans 36:3-21

Schick RS, Loarie SR, Colchero F, Best BD and others (2008) Understanding movement data and movement processes: current and emerging directions. Ecol Lett 11: $1338-1350$

Scott JM, Heglund PJ, Morrison ML (eds) (2002) Predicting species occurrences: issues of accuracy and scale. Island Press, Washington, DC

Shaffer SA, Weimerskirch H, Costa DP (2001) Functional significance of sexual dimorphism in wandering albatrosses, Diomedea exulans. Funct Ecol 15:203-210

Shaffer SA, Costa DP, Weimerskirch H (2003) Foraging effort in relation to the constraints of reproduction in freeranging albatrosses. Funct Ecol 17:66-74

Shaffer SA, Tremblay Y, Awkerman JA, Henry RW and others (2005) Comparison of light- and SST-based geolocation with satellite telemetry in free-ranging albatrosses. Mar Biol 147:833-843

Shaffer SA, Tremblay Y, Weimerskirch H, Scott D and others (2006) Migratory shearwaters integrate oceanic resources across the Pacific Ocean in an endless summer. Proc Natl Acad Sci USA 103:12799-12802

> Shaffer SA, Weimerskirch H, Scott D, Pinaud D and others (2009) Spatio-temporal habitat use of breeding sooty shearwaters Puffinus griseus. Mar Ecol Prog Ser 391: 209-220

Silverman ED, Veit RR, Nevitt GA (2004) Nearest neighbors as foraging cues: information transfer in a patchy environment. Mar Ecol Prog Ser 277:25-35

Skov H, Prins E (2001) Impact of estuarine fronts on the dispersal of piscivorous birds in the German Bight. Mar Ecol Prog Ser 214:279-287

Skov H, Humphreys E, Garthe S, Geitner K and others (2008) Application of habitat suitability modelling to tracking data of marine animals as a means of analyzing their feeding habitats. Ecol Model 212:504-512

Sokolov S (2008) Chlorophyll blooms in the Antarctic Zone south of Australia and New Zealand in reference to the Antarctic Circumpolar Current fronts and sea ice forcing. J Geophys Res C 113:C03022, doi:10.1029/2007 JC004329

Soutullo A, Cadahia L, Urios V, Ferrer M, Negro JJ (2007) Accuracy of lightweight satellite telemetry: a case study in the Iberian Peninsula. J Wildl Manage 71:1010-1015

Spear LB, Ballance LT, Ainley DG (2001) Response of seabirds to thermal boundaries in the tropical Pacific: the thermocline versus the Equatorial Front. Mar Ecol Prog Ser 219: 275-289

Stahl JC, Sagar PM (2000) Foraging strategies and migration of southern Buller's albatrosses Diomedea b. bulleri breeding on the Solander Is., New Zealand. J R Soc NZ 30: 319-334

Stark JD, Donlon CJ, Martin MJ, McCulloch ME (2007) OSTIA: an operational, high resolution, real time, global sea surface temperature analysis system. Proc Oceans 07, Aberdeen, Scotland, UK, 18-21 June 2007. IEEE, Piscataway, NJ, p 1-4

Steiner I, Burgi C, Werffeli S, Dell'Omo G and others (2000) A GPS logger and software for analysis of homing in pigeons and small mammals. Physiol Behav 71:589-596

Suryan RM, Sato F, Balogh GR, Hyrenbach KD, Sievert PR, Ozaki K (2006) Foraging destinations and marine habitat use of short-tailed albatrosses: a multi-scale approach using first-passage time analysis. Deep-Sea Res II 53:370-386

Suryan RM, Anderson DJ, Shaffer SA, Roby DD and others (2008) Wind, waves, and wing loading: morphological specialization may limit range expansion of endangered albatrosses. PLoS One 3:e4016

Swihart RK, Slade NA (1985) Testing for independence of observations in animal movements. Ecology 66:1176-1184

> Teo SLH, Boustany A, Blackwell S, Walli A, Weng KC, Block BA (2004) Validation of geolocation estimates based on light level and sea surface temperature from electronic tags. Mar Ecol Prog Ser 283:81-98

> Thompson D, Moss SEW, Lovell P (2003) Foraging behaviour of South American fur seals Arctocephalus australis: extracting fine scale foraging behaviour from satellite tracks. Mar Ecol Prog Ser 260:285-296

Thorpe SE, Stevens DP, Heywood KJ (2005) Comparison of two time-variant forced eddy-permitting global ocean circulation models with hydrography of the Scotia Sea. Ocean Model 9:105-132

Tremblay Y, Shaffer SA, Fowler SL, Kuhn CE and others (2006) Interpolation of animal tracking data in a fluid environment. J Exp Biol 209:128-140

Tremblay Y, Roberts AJ, Costa DP (2007) Fractal landscape method: an alternative approach to measuring arearestricted searching behavior. J Exp Biol 210:1489

- Tremblay Y, Bertrand S, Henry RW, Kappes MA, Costa DP, Shaffer SA (2009) Analytical approaches to investigate seabird-environment interactions: a review. Mar Ecol Prog Ser 391:153-163

> Tuck GN, Polacheck T, Bulman CM (2003) Spatio-temporal trends of longline fishing effort in the Southern Ocean and implications for seabird bycatch. Biol Conserv 114:1-27

Turchin P (1998) Quantitative analysis of movement: measuring and modeling population redistribution in animals and plants. Sinauer Associates, South Yarra, Australia

Urios V, Soutullo A, Lopez-Lopez P, Cadahia L, Liminana R, Ferrer M (2007) The first case of successful breeding of a golden eagle Aquila chrysaetos tracked from birth by satellite telemetry. Acta Ornithol 42:205-209

Uz BM, Yoder JA (2004) High frequency and mesoscale variability in SeaWiFS chlorophyll imagery and its relation to other remotely sensed oceanographic variables. Deep-Sea Res II 51:1001-1017 
Verity PG, Smetacek V (1996) Organism life cycles, predation, and the structure of marine pelagic ecosystems. Mar Ecol Prog Ser 130:277-293

Vilchis LI, Ballance LT, Fiedler PC (2006) Pelagic habitat of seabirds in the eastern tropical Pacific: effects of foraging ecology on habitat selection. Mar Ecol Prog Ser 315: 279-292

Vincent C, McConnell BJ, Ridoux V, Fedak MA (2002) Assessment of ARGOS location accuracy from satellite tags deployed on captive gray seals. Mar Mamm Sci 18:156-166

Wakefield ED, Phillips RA, Matthiopoulos J, Fukuda A, Higuchi H, Marshall GJ, Trathan P (in press) Wind field and sex constrain the flight speeds of central place foraging albatrosses. Ecol Monogr

Waugh SM, Weimerskirch H (2003) Environmental heterogeneity and the evolution of foraging behaviour in long ranging albatrosses. Oikos 103:374-384

Waugh SM, Weimerskirch H, Cherel Y, Shankar U, Prince PA, Sagar PM (1999) Exploitation of the marine environment by two sympatric albatrosses in the Pacific Southern Ocean. Mar Ecol Prog Ser 177:243-254

Weimerskirch H (1992) Reproductive effort in long-lived birds: age-specific patterns of condition, reproduction and survival in the wandering albatross. Oikos 64:464-473

> Weimerskirch H (2007) Are seabirds foraging for unpredictable resources? Deep-Sea Res II 54:211-223

- Weimerskirch H, Guionnet T (2002) Comparative activity pattern during foraging of four albatross species. Ibis 144: $40-50$

Weimerskirch H, Salamolard M, Sarrazin F, Jouventin P (1993) Foraging strategy of wandering albatrosses through the breeding season: a study using satellite telemetry. Auk 110: 325-342

Weimerskirch H, Doncaster CP, Cuenot-Chaillet F (1994) Pelagic seabirds and the marine environment: foraging patterns of wandering albatrosses in relation to prey availability and distribution. Proc R Soc Lond B 255:91-97

Weimerskirch H, Cherel Y, Cuenot-Chaillet F, Ridoux V (1997a) Alternative foraging strategies and resource allocation by male and female wandering albatrosses. Ecology 78:2051-2063

Weimerskirch H, Wilson RP, Lys P (1997b) Activity pattern of foraging in the wandering albatross: a marine predator with two modes of prey searching. Mar Ecol Prog Ser 151: $245-254$

Weimerskirch H, Catard A, Prince PA, Cherel Y, Croxall JP (1999) Foraging white-chinned petrels Procellaria aequinoctialis at risk: from the tropics to Antarctica. Biol Conserv 87:273-275

Weimerskirch H, Guionnet T, Martin J, Shaffer SA, Costa DP (2000) Fast and fuel efficient? Optimal use of wind by flying albatrosses. Proc R Soc Lond B 267:1869-1874

Weimerskirch H, Bonadonna F, Bailleul F, Mabille G, Dell'Omo G, Lipp HP (2002) GPS tracking of foraging albatrosses. Science 295:1259

Weimerskirch H, Le Corre M, Jaquemet S, Potier M, Marsac F (2004) Foraging strategy of a top predator in tropical waters: great frigatebirds in the Mozambique Channel.

Editorial responsibility: Scott Shaffer,

Santa Cruz, California, USA
Mar Ecol Prog Ser 275:297-308

Weimerskirch H, Le Corre M, Ropert-Coudert Y, Kato A, Marsac F (2005) The three-dimensional flight of redfooted boobies: adaptations to foraging in a tropical environment? Proc R Soc Lond B 272:53-61

Weimerskirch H, Åkesson S, Pinaud D (2006a) Postnatal dispersal of wandering albatrosses Diomedea exulans: implications for the conservation of the species. J Avian Biol 37 : $23-28$

Weimerskirch $\mathrm{H}$, Le Corre M, Ropert-Coudert Y, Kato A, Marsac F (2006b) Sex-specific foraging behaviour in a seabird with reversed sexual dimorphism: the red-footed booby. Oecologia 146:681-691

Weimerskirch H, Pinaud D, Pawlowski F, Bost CA (2007) Does prey capture induce area-restricted search? A fine-scale study using GPS in a marine predator, the wandering albatross. Am Nat 170:734-743

> Weimerskirch H, Le Corre M, Bost CA (2008) Foraging strategy of masked boobies from the largest colony in the world: relationship to environmental conditions and fisheries. Mar Ecol Prog Ser 362:291-302

Wiens JA (1976) Population responses to patchy environments. Annu Rev Ecol Syst 7:81-120

Wiens JA, Stenseth NC, Vanhorne B, Ims RA (1993) Ecological mechanisms and landscape ecology. Oikos 66: 369-380

Wilson RP, Grémillet D, Syder J, Kierspel MAM and others (2002) Remote-sensing systems and seabirds: their use, abuse and potential for measuring marine environmental variables. Mar Ecol Prog Ser 228:241-261

Wittenburger JF, Hunt GL (1971) Sea bird ecology and the marine environment. In: Farner DS, King JR, Parkes KC (eds) Avian biology, Vol 8. Academic Press, New York, p $1-78$

Wood SN (2006) Generalized additive models: an introduction with R. Chapman \& Hall/CRC, Boca Raton, FL

Wood AG, Naef-Daenzer B, Prince PA, Croxall JP (2000) Quantifying habitat use in satellite-tracked pelagic seabirds: application of kernel estimation to albatross locations. J Avian Biol 31:278-286

Woodward RH, Gregg WW (1998) An assessment of SeaWiFS and MODIS ocean coverage. Report No. NASA/TM-1998208607, NASA, Goddard Space Flight Center, Greenbelt, MD

- Worm B, Sandow M, Oschlies A, Lotze HK, Myers RA (2005) Global patterns of predator diversity in the open oceans. Science 309:1365-1369

Wynne-Edwards VC (1962) Animal dispersion in relation to social behaviour. Oliver \& Boyd, Edinburgh

Xavier JC, Croxall JP, Trathan PN, Wood AG (2003) Feeding strategies and diets of breeding grey-headed and wandering albatrosses at South Georgia. Mar Biol 143:221-232

Yasuda T, Arai N (2005) Fine-scale tracking of marine turtles using GPS-ARGOS PTTs. Zool Sci 22:547-553

Zawada DG, Zaneveld JRV, Boss E, Gardner WD, Richardson MJ, Mishonov AV (2005) A comparison of hydrographically and optically derived mixed layer depths. J Geophys Res C 110:C11001, doi:10.1029/2004JC002417

Submitted: May 20, 2009; Accepted: July 7, 2009

Proofs received from author(s): August 10, 2009 